Zabytkoznawstwo i Konserwatorstwo XXXIX, Toruń 2010

Teresa Łękawa-Wysłouch

Uniwersytet Mikołaja Kopernika w Toruniu

\title{
Uzupełnianie ubytków zapraw w malowidłach na płótnie - przegląd materiałów i metod*
}

Konserwator-restaurator dzieł sztuki nierzadko w swej pracy styka się Ten techniczny zabieg jest wręcz powszechny, jako że zniszczenia gruntów występują niezwykle często. Biorąc pod uwagę różnorodność obiektów wymagających interwencji konserwatora-restauratora, nie dziwi fakt istnienia i funkcjonowania rozlicznych receptur kitów. Uzupełnienie ubytku zaprawy, zwane powszechnie kitem, powinno spełniać określone wymagania i w każdym przypadku winno być dostosowane do indywidualnych właściwości i potrzeb obiektu.

\section{Kryteria wyboru materiałów do uzupełniania ubytków zapraw}

Wymagania, jakie stawia się masom stosowanym do uzupełniania ubytków zapraw w obrazach na płótnie, nie odbiegają w zasadniczy sposób od wymagań stawianych wszelkiego rodzaju materiałom wprowadzanym w obiekt w procesie konserwacji i restauracji. Dobór środków jest uzależniony od całego, nierzadko wieloelementowego, zespołu warunków. Jednakże, mimo

* Artykul powstał na podstawie pracy magisterskiej wykonanej przez autorke pod kier. prof. dr Marii Roznerskiej w Zakładzie Konserwacji Malarstwa i Rzeźby Polichromowanej Instytutu Zabytkoznawstwa i Konserwatorstwa UMK w Toruniu w 1999 r. 
całej złożoności sytuacji, muszą istnieć jasno sformułowane kryteria doboru materiałów i takich ich cech, które czynią je dopuszczalnymi w procesie konserwacji i restauracji.

W przypadku wycinkowego w tym procesie, aczkolwiek ważnego, zabiegu uzupełniania ubytków zapraw mamy do czynienia zarówno z aspektem technicznym, jak i estetycznym. Kit spełnia ważną funkcję w stosunku do odsłoniętych krawędzi warstwy malarskiej i gruntu, stanowiąc ochronę przed uszkodzeniem przez czynniki mechaniczne i zabezpieczenie przed dalszą utratą substancji. Jego umieszczenie w ubytku pozwala także na zbliżenie, lub nawet wyrównanie współczynników przenikania par przez strukturę obrazu, co przeciwdziała powstawaniu naprężeń, nierównomiernej pracy i postępującemu niszczeniu obiektu (np. gdy jednocześnie występuja obok siebie partie zawierające wszystkie warstwy technologiczne i partie odsłoniętego płótna).

Estetyczna funkcja uzupełniania jest nie mniej ważna, gdyż decyduje ona o końcowym wyrazie i oddziaływaniu dzieła sztuki. Dobrze założony i opracowany kit, będący podłożem dla retuszu barwnego, w znacznym stopniu przyczynia się do odtworzenia artystycznej jedności obrazu i do niezakłóconego odczytania jego przekazu. Natomiast wadliwie uzupełniony ubytek, niedostosowany poziomem i strukturą do otaczającej go substancji zabytkowej, może w poważny sposób obniżyć jakość odbioru i wpłynąć na zubożenie walorów artystycznych. Podobnie pozostawienie nieuzupełnionych ubytków może niepokoić i fałszować odbiór dzieła sztuki w większym stopniu niż dobrze wykonana odróżnialna rekonstrukcja.

Decyzji o zastosowaniu konkretnej masy do uzupełnienia ubytków zaprawy powinna towarzyszyć refleksja dotycząca zarówno samego konserwowanego obrazu, cech, którymi kit powinien się odznaczać, jak i warunków, jakim musi sprostać wypełnienie.

Pożądane jest, aby kit był stosunkowo prosty do przygotowania, a jeśli będzie bardziej skomplikowany, aby pozostawał użyteczny przez dłuższy czas, zwłaszcza gdy ubytki są liczne lub rozległe. Stosowana masa uzupełniająca powinna być łatwa w użyciu, mieć konsystencje pozwalającą na zakładanie w ubytki bez rozlewania się poza ich granice, a jednocześnie nie powinna być zbyt lepka i nie może przywierać podczas aplikowania do narzędzi oraz do form czy odcisków, za pomocą których ma być odwzorowana faktura 
w mokrym kicie. Masa do uzupełnień powinna być na tyle plastyczna, by dawać możliwość opracowania wszelkiego rodzaju faktury - od równej i gładkiej do bogatej i impastowej. Kit powinien charakteryzować się odpowiednią szybkością wysychania, która pozwoli na pracę nad wypełnieniem. Twardość wyschniętego kitu nie może być większa niż otaczających go warstw oryginalnych, aby nie narażać ich na uszkodzenie podczas wyrównywania i opracowywania powierzchni wypełnienia lub podczas ewentualnego usuwania wypełnienia z ubytku. Kity nie mogą też być przyczyną deformacji płótna, co jednak jest prawdopodobne w przypadku zbyt mocno sklejonych, twardych uzupełnień zaprawy, zwłaszcza w większych ubytkach.

Istotną kwestią jest także bezpieczeństwo użycia, brak toksycznych substancji lotnych szkodliwych dla zdrowia. Z kolei z uwagi na bezpieczeństwo malowidła skład kitu powinien być odpowiednio skomponowany pod względem chemicznym. Wymagana jest obojętnośćchemiczna i pH niewpływające na degradacje substancji zabytkowej - już podczas wprowadzania w ubytek, ale przede wszystkim po umieszczeniu w nim, np. kit o kwaśnym odczynie może powodować degradację celulozy w płótnie.

Wskazane jest, aby kit nie ulegał zmianom objętości w trakcie wysychania i zestalania lub kurczył się w jak najmniejszym stopniu. Im większy jest udział wypełniaczy w kicie i im cieńsza warstwa jest stosowana, tym mniejsza jest możliwość skurczenia się kitu podczas wysychania. Substancje lotne nie mogą mieć zbyt dużego udziału w masie kitu, gdyż to właśnie ich odparowanie powoduje skurcz, a nierzadko także pekanie wypełnienia. Jest to szczególnie niepożądana cecha w przypadku głębokich i rozległych ubytków, gdy konieczne staje się wielokrotne uzupełnianie aplikowanego kitu. Skurcz kitu jest niewskazany także w sytuacji, gdy wypełnienie ma mieć fakturę nadaną za pomocą formy lub odlewu, gdyż może dać spłaszczoną i odmienną od zamierzonej powierzchnię, a nawet spowodować utratę odciśniętej faktury.

Kit założony w ubytek powinien dobrze zwilżyć i przylgnąć zarówno do podłoża, jak i do krawędzi ubytków, co może być trudne, jeśli zastosuje się np. kit o wodorozcieńczalnym spoiwie na tłuste, niezwilżalne podłoże. Adhezja i wytrzymałość spoiny nie powinny słabnąć z upływem czasu, aczkolwiek w sytuacji wystąpienia silnych naprężeń, np. napinania płótna na krosnach lub nawijania na walec, lepiej, jeśli kit oddzieli się w miejscu połą- 
czenia z oryginalną substancją, niż miałby powodować jej pękanie i niszczenie. Takie przypadki narzucają również wymóg możliwie wysokiej elastyczności stawiany materiałom wypełniającym ubytki. Stopień elastyczności powinien być zbliżony do elastyczności warstw oryginalnych, tak aby możliwe było transportowanie dużych płócien, zdjętych z krosien i nawiniętych na walce. Zbyt sztywne kity w takich okolicznościach mogą pękać, oddzielać się od krawędzi ubytków, a nawet od płóciennego podłoża. Elastyczność kitu powinna być wystarczająca także w sytuacji, gdy obraz naciągnięty na krosna pozostaje w zmiennych warunkach klimatycznych, które nierzadko wywołują gwałtowne reakcje płótna, polegające na naprzemiennym kurczeniu się i rozprężaniu. Odpowiedni kit powinien być odporny na wymienione czynniki, podążać za ruchami podobrazia, poddawać się im bez pękania, odpowiadać na zmiany wilgotności i temperatury w sposób zbliżony do reakcji oryginalnego otoczenia.

Wprowadzony materiał nie może reagować ze składnikami obrazu ani wpływać na zmiany kolorystyczne lub tonalne w strukturze zabytkowej. Lokalne przebarwienia mogą wystapić w przypadku, gdy np. zastosuje się kit woskowo-żywiczny do uzupełniania ubytków zaprawy w obrazie o chudej warstwie malarskiej, ale także, gdy kit jest przygotowany lub rozcieńczany z użyciem wody z kranu, zawierającej sole żelazowe.

Materiały, z których skomponowano kit, nie powinny stanowić atrakcyjnej pożywki dla mikroorganizmów - grzybów i bakterii - co, w przeciwnym razie, może być przyczyną zakażenia obiektu. W związku z niebezpieczeństwem ataku drobnoustrojów nie jest też wskazane, aby kit odznaczał się nadmierną higroskopijnością, jednakże właściwość ta w pewnym, ograniczonym zakresie jest pożądana, gdyż może pozytywnie wpływać na poprawę elastyczności wypełnienia. Innym zagrożeniem związanym z nadmierną higroskopijnością kitu jest uwrażliwienie na urazy mechaniczne oraz powodowanie pociemnienia lub zmętnienia uzupełnień warstwy malarskiej w wyniku lokalnego zawilgocenia.

Niezbędną cechą dobrego wypełnienia, które w dalszej kolejności ma być pokryte barwnym uzupełnieniem, jest dobra zwilżalność przez spoiwo i odpowiednie chłonięcie go przez kit. Niezwilżalne uzupełnienie ubytku znacznie utrudnia dalszą prace i wpływa na gorszą przyczepność powłoki barwnej. Konieczne jest dobranie właściwego kitu do rodzaju spoiwa wystę- 
pującego w farbach przewidzianych do punktowania lub użycie substancji poprawiających zwilżalność i rozlewność spoiwa oraz adhezję powłoki barwnego uzupełnienia. Z drugiej strony, zbyt chłonny kit może powodować wchłanianie spoiwa farby, przyczyniając się do niskiej trwałości barwnych wypełnień i ich pudrowania. W przypadku stosowania werniksu retuszerskiego po uzupełnieniu i opracowaniu ubytków - zbyt chłonny kit może wchłaniać werniks tak, że nie tworzy warstwy izolacyjnej, co uniemożliwia wyrównanie stopnia błyszczenia partii oryginalnych i uzupełnianych. Sytuacja taka w poważnym stopniu utrudnia późniejsze punktowanie, a także uzyskanie jednorodnej powierzchni przy nanoszeniu werniksu końcowego. Uzupełniane fragmenty, mimo że świetnie dopasowane fakturalnie i kolorystycznie, mogą wyodrębniać się w postaci matowych, niepokojących swą odmiennością partii, wyłącznie z powodu nadmiernej chłonności kitu.

Kit powinien charakteryzować się stabilnością i trwałością po wprowadzeniu do obiektu, tj. sam nie może podlegać zmianom chemicznym i fizycznym. Wymagana jest odporność na starzenie, brak tendencji spoiwa wiążącego do sieciowania lub degradacji. Wprowadzone w ubytek wypełnienie musi pozwalać na usunięcie, lecz nie powinno się łatwo rozpuszczać, aby możliwe było zmycie werniksu i punktowań bez naruszenia powierzchni dobrze opracowanego kitu. Wypełnienie powinno być odwracalne z zastosowaniem metod bezpiecznych dla substancji oryginalnej we wszystkich warstwach nawet po upływie długiego czasu.

\section{Charakterystyka środków stosowanych do uzupełniania ubytków zapraw}

Uzupełnianie ubytków zaprawy jest czynnością poprzedzającą wykonanie barwnych uzupełnień i rekonstrukcji warstwy malarskiej. Przyjmuje się, że kończy ona etap konserwacji i rozpoczyna prace związane z restauracją ${ }^{1}$. Materiały stosowane do uzupełniania ubytków zaprawy, zawierające jedną lub kilka substancji wypełniających połączonych spoiwem, zwane są powszech-

1 E. W. Kudriawcew, Tiechnika restawracji kartin, Moskwa 1948, s. 116-117. 
nie kitami. Celem zabiegu jest wypełnienie uszkodzenia w zaprawie i warstwie malarskiej w taki sposób, aby zostały zlikwidowane wszelkie wtórne nierówności i odtworzona powierzchnia zgodna z sąsiadującą z ubytkiem oryginalną substancją, przez zintegrowanie i powiązanie strukturalne tych partii. Tak wykonane uzupełnienie ubytków stanowi podłoże dla scalenia barwnego i umożliwia przywrócenie pełni walorów estetyczno-przedstawieniowych konserwowanego obrazu. Jakość wypełnienia i jego zachowanie w czasie będa w dużym stopniu zależały od dokonania wyboru materiału uwzględniającego specyfike, indywidualne wymagania i ograniczenia, wiążące się z konserwowanym obrazem. W literaturze konserwatorskiej jeszcze w latach 70. XX wieku można znaleźć opinię, że materiały wprowadzone do obiektu w czasie konserwacji powinny być takie same jak oryginalne. Od lat 80. większy nacisk kładzie się na dopasowanie właściwości substancji pierwotnych i wtórnych. Wydaje się to o tyle uzasadnione, że wprowadzone, analogiczne pod względem składu materiały nie zawsze mają identyczne właściwości. Należy bowiem brać pod uwagę fakt, że oryginalna substancja podlegała przez długie lata działaniu czynników powodujących jej starzenie, podczas gdy świeżo sporządzony kit charakteryzuje się wyjściowymi właściwościami kompozycji, wolnymi od niedoskonałości pojawiających się z upływem czasu. Ponadto w przypadku, gdy oryginalny materiał jest obciążony poważnymi wadami, trudno zgodzić się na to, aby świadomy tego konserwator, podporządkowując się kryterium zgodności materiałów pierwotnych i wtórnych, wprowadzał analogiczne wypełnienia. Przykładem może być tu obraz namalowany na olejnej zaprawie, wymagający uzupełnienia jej ubytków. Kłopotliwe mogłoby się też okazać dobranie odpowiedniego materiału w przypadku obrazu, który w trakcie poprzednich ingerencji został w całej strukturze nieodwracalnie przesycony wtórnym spoiwem, na skutek czego zmienił się pierwotny charakter malowidła.

Zauważa się tendencję do zastępowania materiałów naturalnych, krytykowanych w literaturze za ujawniające się z czasem niedoskonałości, syntetycznymi lub do łączenia ich w celu wyeliminowania wad i uzupełnienia zalet. Publikacje propagujące te rozwiązania przedstawiają najcześciej wyniki badań, umożliwiające ocenę właściwości środków syntetycznych. Jest to zapewne rezultat zgłaszanych w dyskusjach postulatów o zwracanie uwagi na charakterystykę starzeniową i odwracalność tych materiałów. O ile bowiem 
materiały tradycyjne zostały już stosunkowo dobrze rozpoznane pod kątem wad i sposobu starzenia się, o tyle materiały syntetyczne wciąż budzą pod tym względem wiele wątpliwości.

Konserwator ma do dyspozycji całą gamę kitów, różniących się między sobą zarówno zestawem komponentów, jak i ich proporcjami. Literatura przedmiotu, systematyzując zagadnienia, najczęściej proponuje podział ze względu na typy spoiwa wiążącego. Receptury przytaczane w opracowaniach ogólnych, jak również w publikacjach relacjonujących przebieg konkretnych realizacji konserwatorskich nie zawsze są precyzyjne i ścisłe - być może w związku z podkreślaną niekiedy koniecznością każdorazowego sprawdzenia podstawowych właściwości uzyskanej mieszaniny oraz dostosowania ich do jednostkowego przypadku. Wcześniejsze publikacje rzadko różnicują receptury w zależności od typów podłoża. W literaturze ostatnich kilkunastu lat wskazuje się na odmienne wymagania podłoży tekstylnych, drewnianych czy metalowych w stosunku do kitów. Zwraca się także uwage na stosowanie składników najwyższego gatunku w przypadku materiałów naturalnych, natomiast w odniesieniu do materiałów syntetycznych zaleca się użycie środków o odpowiednich parametrach technicznych. Daje się też zauważyć znaczna doza rezerwy w stosunku do gotowych firmowych substancji - polecanych przez producentów zarówno do uzupełniania ubytków zapraw i gruntowania, jak i do tych, które daja potencjalnie możliwości wykorzystania w tym celu. Produkty te nie są polecane ze względu na brak informacji o składzie, brak wyników specjalistycznych badań, co sprawia, że ich trwałość i odwracalność są trudne do przewidzenia. Zauważa się także, że skład materiałów fabrycznych jest z reguły tak komponowany, aby uzyskać optymalny stosunek spoiwa i wypełniacza. Modyfikowanie ich przez dodatki, np. wypełniacza w przypadku zbyt płynnej masy lub znacznego skurczu w trakcie wysychania, może skutkować pogorszeniem niektórych właściwości, takich jak np. adhezja do podłoża.

Stosowane są następujące rodzaje kitów:

1. na bazie spoiw naturalnych:

- klejowy,

- emulsyjny,

- olejny,

- woskowy lub woskowo-żywiczny; 
2. na bazie żywic syntetycznych:

- na BEVA 371,

- na polialkoholu winylu,

- na polioctanie winylu,

- poliakrylowe.

\subsection{Kity oparte na spoiwach naturalnych}

\section{Kity klejowe}

Kity klejowe zawierają naturalne wodne spoiwo i wypełniacze. W razie konieczności mogą być barwione pigmentami, a ich właściwości można modyfikować przez dodatek różnych materiałów. „Czysty” kit klejowy jest taki sam jak kredowe grunty Starych Mistrzów. Obok olejnych, kity klejowe są historycznie najstarszą postacią materiałów stosowanych do wypełniania ubytków i do dzisiejszych czasów nie wyszły one z użycia². O ich popularności decyduje przede wszystkim łatwość przygotowania i opracowania ${ }^{3}$. W przeważającej większości kity klejowe zawierają jako spoiwo kleje glutynowe, różniące się właściwościami, co jest uzależnione od cech produktu wyjściowego. Podkreśla się fakt, że to właśnie spoiwo jest składnikiem, który determinuje finalne właściwości gotowego kitu. Zwraca się jednocześnie uwage, że kleje używane w tradycyjnych kitach są wrażliwe na atak mikroorganizmów: grzybów, pleśni i bakterii. Porastaniu klejów w warunkach wysokiej wilgotności nie zapobiegają dodatki fungicydów, których działanie jest ograniczone w czasie. Ponadto kleje organiczne w wyniku starzenia mają tendencje do żółknięcia, stawania się kruchymi lub twardymi ${ }^{4}$. Stąd niezwykle istotną

2 E. Szmit-Naud, Trwałość optyczna retuszy w malarstwie sztalugowym, rezultaty ankiety, „Biuletyn Informacyjny Konserwatorów Dzieł Sztuki”, 1999, t. 10, nr 1 (36), s. 56-57. Z wyników ankiety przeprowadzonej przez autorkę wśród konserwatorów polskich i zagranicznych wynika, że kity klejowe z klejem glutynowym są jednymi z najczęściej stosowanych kitów.

3 B. Slansky, Technika malarstwa, t. 2: Badanie i konserwowanie obrazów, Warszawa 1965, s. 237.

4 D. M. Falvey, The advantages of Moviol (polyvinyl alkohol): Comparative studies of organic and synthetic binding media for fillers for paintings on canvas, [w:] ICOM, 6th Triennial Meeting, Ottawa 1981, s. 81/2/13-2. 
kwestią jest wybór spoiwa w odpowiednim gatunku - już w chwili przygotowywania kitu. Szczególnie cenne i przydatne do sporządzania kitów klejowych są najlepsze, najbardziej elastyczne gatunki klejów glutynowych, jak: króliczy, zajęczy, karuk rosyjski, klej skórny.

Literatura wzmiankuje również gumę arabską i tragantową oraz kazeinę jako spoiwa stosowane niegdyś do kitów, a jako substancja uzupełniająca, zapewniająca uzyskanie większej adhezji, kohezji i elastyczności, wymieniany jest miód ${ }^{5}$. Jeszcze w 1948 roku E. W. Kudriawcew ${ }^{6}$ polecał tradycyjny grunt do uzupełniania ubytków, składający się z roztworu kleju rybiego, kredy pławionej i miodu dla nadania elastyczności. Współczesna literatura podchodzi z dużą rezerwą do zagadnienia plastyfikowania kitów. W. Ślesiński ${ }^{7}$ pisze, że do kitów klejowo-kredowych można ewentualnie dodać kilka kropel gliceryny, ale generalnie nie poleca stosowania plastyfikatorów, głównie ze względu na zdolność absorbowania przez nie wody, co może powodować mętnienie retuszy ${ }^{8}$, szczególnie wykonanych pigmentami ziemnymi, a także rozkład kleju przez pleśnie, jeśli plastyfikatory są użyte w zbyt dużej ilości9 M. Doerner ${ }^{10}$ wzmiankuje, że dodatek gliceryny, mydła i miodu do kitu nie jest potrzebny. K. Chmiel-Wajda ${ }^{11}$, która przeprowadziła badania na trzech grupach kitów (m.in. z klejem glutynowym) z plastyfikatorami i bez ich udziału, stwierdza, że substancje te w poważnym stopniu wpływają na wzrost elastyczności kitów. Jednakże nie poleca ona dodawania do kitów poliglikolu etylenowego 600 i miodu, które będąc zbyt higroskopijne, przyczyniają się do zawilgocenia obrazów, co osłabia ich wytrzymałość mechaniczną i stwa-

5 K. Nicolaus, The restoration of paintings, Cologne 1998, s. 238, [za:] C. Wagner, Arbeitsweisen und Anschauungen in der Gemälderestaurierung um 1800. Dissertation, Munich 1988, s. 46.

6 E. W. Kudriawcew, op. cit., s. 117.

7 W. Ślesiński, Konserwacja zabytków sztuki, t. 1: Malarstwo sztalugowe i ścienne, Warszawa 1989, s. 91.

$8 \quad$ B. Slansky, Technika malarstwa, t. 2: Badanie, s. 237.

9 Idem, Technika malarstwa, t. 1: Materiaty do malarstwa i konserwacji, Warszawa 1960, s. 277.

10 M. Doerner, Materiaty malarskie i ich zastosowanie, Warszawa 1975, s. 301.

11 K. Chmiel-Wajda, Reperacje w obrębie ubytków warstw malarskich w obrazach na podłożu tekstylnym, maszynopis pracy magisterskiej wykonanej w ZKZR UMK pod kier. doc. J. Wolskiego, Toruń 1973. 
rza dogodne warunki do rozwoju mikroorganizmów. Uważa, że dobrym plastyfikatorem jest olej lniany polimeryzowany, mimo że powoduje ograniczenie chłonności i czyni kit trudniejszym do opracowania po wyschnięciu. Rozwiązanie problemu autorka widzi w stosowaniu tego plastyfikatora łącznie z terpentyną wenecką, która częściowo zlikwiduje te wady ${ }^{12}$. Zwykły olej lniany jest gorszym plastyfikatorem niż polimeryzowany, gdyż starzeje się szybciej od niego, powoduje znaczne żółknięcie i ciemnienie kitów ${ }^{13}$. Olej i pokost lniany mają większą skłonność do żółknięcia, gdy są zemulgowane z klejem, niż gdy występują w normalnych warunkach ${ }^{14}$. K. Nicolaus ${ }^{15}$ dopuszcza uzupełnianie masy kitującej olejem lnianym, olejem wystałym ${ }^{16}$ (stand oil) lub niewielką ilością płynnej mieszaniny woskowo-żywicznej, jeśli to konieczne. I. Sandner ${ }^{17}$, opierając się na wynikach testów starzeniowych, stwierdza jednak, że na dłuższą mete plastyfikatory, takie jak terpentyna wenecka czy gotowany olej lniany, są niekorzystne, gdyż wypełnienia z tymi dodatkami również mają tendencje do pękania.

Stosowane jako wypełniacze kitów klejowych zarówno kreda szampańska, pławiona, biały bolus, jak i kreda bolońska (gips pławiony), z ewentualnym dodatkiem kolorowych pigmentów (zwykle ziemnych), są polecane jako materiały tworzące dobre kity. W przypadku kolorowych mas związanych środkiem wodnym należy liczyć się z możliwością wystąpienia zmiany tonu barwnego podczas wysychania kitu i zabiegu izolowania ${ }^{18}$.

W literaturze i w różnych ośrodkach konserwatorskich funkcjonują receptury zawierające różnorodne ilości i proporcje poszczególnych składników. Najcześciej poleca się około 10\% stężenie kleju dla uzyskania gęstej

12 Ibidem, s. 53-54.

13 Ibidem, s. 52.

14 B. Slansky, Technika malarstwa, t. 1: Materiały, s. 278.

15 K. Nicolaus, op. cit., s. 238.

16 Olej wystały - niem. Standöl, ang. stand oil - to, jak podaje Hopliński, olej gotowany w strumieniu kwasu weglowego, bez użycia innych katalizatorów, co powoduje jego wolniejsze wysychanie niż olejów surowych. Por. J. Hopliński, Farby i spoiwa malarskie, Ossolineum 1990, s. 38.

17 I. Sandner, The use of synthetic resins in picture conservation, both alone and in combination with conventional adhesives, [w:] Resins in Conservation, Scottish Society for Conservation and Research, The proceedings of the Symposium, Edinburgh 1982, s. 6-5.

18 K. Nicolaus, op. cit., s. 238. 
pasty, a niższe, około 6-8\% stężenie, jeśli potrzebny jest rzadszy kit. Podkreśla się jednocześnie, że nie można liczbowo określić właściwych proporcji spoiwa do wypełniacza z uwagi na różnice lepkości pierwszego i chłonności drugiego substratu w różnych gatunkach składników ${ }^{19}$. Optymalna ilość każdego materiału wchodzącego w skład kitu musi być wypracowana metodą prób i błędów; jeśli doda się za dużo wypełniacza, to jego cząstki nie będą ze sobą dostatecznie związane (kohezja będzie zbyt słaba), a równocześnie wypełnienie nie będzie dostatecznie mocno przylegało do podłoża i substancji malarskiej (niewystarczająca adhezja). Taki kit po wyschnięciu może pudrować się lub łuszczyć, będzie też potrzebował silniejszej izolacji, bo niedostatecznie zaizolowany, będzie wchłaniać spoiwo z barwnego uzupełnienia. Nie należy w tym przypadku stosować, dawniej praktykowanego jako środka zaradczego, nasycania kitu olejem, pokostem lub werniksem kopalowym, które z czasem powodują zmiany optyczne, żółknięcie i ciemnienie, w następstwie czego następują deformacje barwne i tonalne barwnego uzupełnienia ${ }^{20}$. Poleca się pozostawienie do spęcznienia odpowiedniej ilości dodanego do wody kleju glutynowego - przynajmniej na kilka godzin lub jedną noc a następnie podgrzanie na łaźni wodnej ${ }^{21}$. Tak przygotowany roztwór kleju jest zdolny do połączenia z wypełniaczami, aż do uzyskania kitu o żądanej konsystencji. Istotną kwestia jest upewnienie się, że spoiwo nie stało się zbyt silne, np. przez odparowanie wody. Kity, które zostały związane zbyt mocno, mają tendencje do pękania i do oddzielania się od podobrazia, zwłaszcza jeśli są założone na duże powierzchnie ${ }^{22}$. Mogą także powodować niszczenie otaczających je warstw oryginalnych ${ }^{23}$.

Zasadniczo właściwie sporządzony kit klejowy ma dobrą przyczepność. Jednakże w przypadku kitów klejowych stosowanych na pozostałości mas woskowo-żywicznych należy mieć świadomość, że pomimo używanych środków adhezyjnych mogą się one wyłuszczać czy oddzielać od podobra-

19 B. Slansky, Technika malarstwa, t. 2: Badanie, s. 237.

20 Ibidem, s. 240.

21 K. Nicolaus, op. cit., s. 238.

22 B. Slansky, Technika malarstwa, t. 2: Badanie, s. 237; W. Ślesiński, Konserwacja zabytków, s. 91.

23 K. Nicolaus, op. cit., s. 238. 
zia. W celu zminimalizowania tego ryzyka literatura konserwatorska proponuje, aby po wyschnięciu, wyszlifowaniu i opracowaniu faktury gotowy kit klejowy wprasować wraz z mieszaniną woskowo-żywiczną ${ }^{24}$. Wydaje się jednak, że jest to rozwiązanie możliwe w przypadku stosunkowo gładkich obrazów, gdzie faktura kitów nie jest zbyt zróżnicowana i nacisk z użyciem podwyższonej temperatury nie spowoduje spłaszczenia impastów. Kity klejowe źle przywierają także do ubytków potraktowanych klejem opartym na dyspersji ${ }^{25}$.

\section{Kity emulsyjne}

Podobnie jak klejowy, kit emulsyjny zawiera klej i kredę lub gips. Po dodaniu do kitu klejowego dużej ilości oleju schnącego lub żywicy staje się on kitem emulsyjnym lub półolejnym. Substancje te zmniejszaja jego chłonność i jednocześnie poprawiają jego elastyczność na tyle, że możliwe staje się zwijanie obrazów na płótnie, w konserwacji których kity emulsyjne zostały zastosowane $^{26}$. Jednakże po upływie pewnego czasu kity te tracą swoją elastyczność ${ }^{27}$. Do innych poważnych wad kitów emulsyjnych, ujawniających się z czasem, zalicza się żółknięcie, za które jest odpowiedzialny użyty w mieszaninie olej ${ }^{28}$. Na niekorzyść tego rodzaju kitów przemawia też fakt, że znacznie trudniej jest wygładzić, polerować i opracować ich powierzchnie, a także oczyścić warstwę malarską z jego pozostałości niż w przypadku kitów klejowo-kredowych. $Z$ tego powodu literatura przedmiotu zaleca, aby czynności te podejmować niezwłocznie po założeniu kitu oraz aby krawędzie ubytków przed przystąpieniem do uzupełniania zabezpieczyć prowizorycznie łatwo rozpuszczającym się werniksem damarowym. Ta ostatnia rada dotyczy zresztą również kitów klejowych ${ }^{29}$. Literatura podaje różne - zarówno pod względem zestawienia komponentów, jak i ich proporcji - receptury

\footnotetext{
24 Ibidem, s. 239.

25 Ibidem, s. 289.

26 B. Slansky, Technika malarstwa, t. 2: Badanie, s. 240.

27 W. Ślesiński, Konserwacja zabytków, s. 91.

28 B. Slansky, Technika malarstwa, t. 2: Badanie, s. 240; W. Ślesiński, Konserwacja za-

29 B. Slansky, Technika malarstwa, t. 2: Badanie, s. 238, 240.
} bytków, s. 91. 
kitów emulsyjnych. B. Slansky ${ }^{30}$ proponuje mieszaninę złożoną z kredy, 10\% kleju i oleju lnianego polimeryzowanego w stosunku 4:1:0,5. W. Ślesiński ${ }^{31}$ do identycznej receptury proponuje dodatek terpentyny weneckiej w ilości 1/10 części. Autor podaje też inny zestaw składników, a mianowicie kredę z 5\% roztworem karuku i olejem lnianym w proporcjach 3:1:1. M. Doerner ${ }^{32}$ poleca, jako dobry kit półkredowy, mase sporządzoną z kleju, kredy, bieli cynkowej i pokostu lnianego, z ewentualnym dodatkiem odpowiedniej farby (pigmentu?) dla podbarwienia do koloru barwnego gruntu. W przypadku zmurszałych obrazów, których nie można dublować na nowe płótno, autor radzi, aby pokost lniany zastąpić werniksem damarowym lub mastyksowym, które nie powodują stwardnienia kitu. Nieco odmienną recepturę kitu emulsyjnego opracował H. Ruhemann ${ }^{33}$, polecając ją jako sprawdzoną i dającą zadowalające efekty. Autor zastosował jako spoiwo klej z olejem zagęszczonym oraz kredę i biel cynkowa jako wypełniacz, a jako plastyfikatora użył wosku pszczelego. Jednakże opinie wielu konserwatorów i badaczy na temat tego kitu są niepochlebne. B. Tańska ${ }^{34}$ zarzuca mu całkowity brak przyczepności do płótna, bardzo złą adhezję retuszy i słabą elastyczność, chwaląc jedynie łatwość opracowania faktury. Zwraca też uwagę na znaczny udział oleju w stosunku do pozostałych składników kitu, co może w przyszłości powodować silne stwardnienie wypełnienia. J. Green i J. Seddon ${ }^{35}$ oceniają kit Ruhemanna jako trudny w przygotowaniu, twardy już po wyschnięciu, ale mający dobrą adhezję do Melinexu, na którym był badany. I. Sandner ${ }^{36}$ nadmienia, że kit ten wykazuje liczne wady, nie wymieniając ich jednak.

30 Ibidem, s. 240.

31 W. Ślesiński, Konserwacja zabytków, s. 91.

32 M. Doerner, op. cit., s. 301.

33 H. Ruhemann, The cleaning of paintings, problems and potentialities, London 1968. Skład kitu: 2 części kredy pozłotniczej + 1 część oleju lnianego zagęszczonego + 1 czesść kleju glutynowego $+5 \%$ wosku pszczelego + biel cynkowa (jako środek antyseptyczny).

34 B. Tańska, Kity na podłożu tekstylnym, maszynopis pracy magisterskiej napisanej pod kier. doc. Z. Wolniewicz w ZKZR UMK, Torun 1977, s. 41-42.

35 J. Green, J. Seddon, A study of materials for filling losses in easel paintings, and their receptiveness to casting of textures, [w:] ICOM Comittee for Conservation, 6th Triennial Meeting, Ottawa 1981, s. 81/2/12-5.

36 I. Sandner, op. cit., s. $6-5$. 
W ramach poszukiwań doskonalszych formuł mas do uzupełniania ubytków obserwuje się próby zastąpienia poszczególnych materiałów składowych, odpowiedzialnych za konkretne wady wypełnień, innymi, dającymi lepsze rezultaty. Materiały naturalne są zastępowane przez syntetyczne lub łączone z nimi. Przykładem takiego kitu może być, chętnie stosowany przez polskich konserwatorów, kit emulsyjny na bazie mieszaniny spoiw syntetycznych: polialkoholu winylowego i metylocelulozy z żywicami naturalnymi: mastyksem i terpentyną wenecką, tzw. „wiedeński” ${ }^{37}$.

\section{Kity olejne}

Kity olejne zawierają schnące oleje użyte jako spoiwo oraz wypełniacze i pigmenty. Spoiwem kitów olejnych mogą być olej lniany, orzechowy, makowy, jak również olej wystały (stand oil) i werniks olejny. Funkcję wypełniaczy pełnią: biel ołowiowa, kreda lub gips, kolorowe pigmenty (najcześciej ziemne). W literaturze wymienia się także krochmal, ostrygi, muszelki i glinę ${ }^{38}$. Kity olejne wraz z klejowymi należą do najstarszych postaci materiałów do wypełnień ubytków. Według W. Ślesińskiego ${ }^{39}$ zakładanie kitów w konserwacji malowideł sztalugowych rozpoczyna się w XVIII wieku i są to właśnie kity sporządzone z werniksu olejnego i glinki (bolusu), a nieco później (w okresie od 1800 do 1918 r.) także olejne. Oprócz świeżo przyrządzanych kitów olejnych, jako tzw. kity pigmentowe, wykorzystywano bezużyteczne już przy malowaniu, zeskrobane z palety malarskiej farby olejne. Do wypełniania małych ubytków stosowano również gęstniejący olej, używany uprzednio przez malarzy do czyszczenia pedzli ${ }^{40}$. Kit olejny w czystej postaci obecnie nie jest wykorzystywany w konserwacji malarstwa prawie wcale.

37 Zgodnie z wynikami ankiety E. Szmit-Naud, kit „wiedeński” znajduje się na trzecim miejscu (po klejowo-kredowych i innych emulsyjnych kitach) pod względem częstotliwości stosowania. Por. E. Szmit-Naud, op. cit., s. 56-57.

38 K. Nicolaus, op. cit., s. 239; Ekonomija Domowa, czyli przepisy tyczace sie gospodarstwa wiejskiego i domowego z dodatkiem objaśnień osobliwości artystycznych wydane przez Tomasza Bartmońskiego inżyniera cywilnego, Warszawa 1856, s. 109.

39 W. Ślesiński, Dawne metody i środki chemiczne stosowane przy konserwacji malarstwa sztalugowego, „Ochrona Zabytków”, 1984, nr 1, s. 26.

40 Dokładna nauka oczyszczania i naprawiania obrazów, olejnemi, woskowemi, wodnemi i suchemi farbami malowanych, Lwów 1845, s. 49-50: „olej ten nabiera przez czyszczenie 
W celu przygotowania kitu olejnego olej schnący dodaje się w niewielkich ilościach do kredy szampańskiej lub bolońskiej i zagniata lub uciera na płycie z wypełniaczem do chwili, gdy kit osiagnnie pożądaną konsystencję. Tłusty kit, z dużą zawartością oleju, schnie powoli, a jego wysychanie nie przebiega od razu na całej grubości. Trudno jest go wykończyć i wypolerować. Początkowo kity olejne charakteryzują się dużą elastycznością, którą z czasem tracą, stając się kruche ${ }^{41}$. Inną ich poważną wadą jest to, że stają się one bardzo twarde i żółkną. Usunięcie nadmiarów i pozostałości kitu z sąsiadującej z ubytkami warstwy malarskiej musi nastąpić tuż po wypełnieniu ubytków, zanim masa wyschnie i stwardnieje.

Pewną odmianą kitu olejnego jest kit bezbarwny i przezroczysty, polecany w przypadku obrazów mających wiele małych, położonych blisko siebie uszkodzeń warstwy malarskiej. Sporządza się go z oleju i białych barwników o najmniejszym stopniu załamania światła. B. Slansky ${ }^{42}$, jako odpowiednie do tego celu, wymienia wodorotlenek glinu i talk. M. Doerner ${ }^{43}$ z kolei pisze, że kit taki wykonuje się ze świeżo strącanego tlenku glinu, który uzyskuje się w postaci białej kłaczkowatej masy albo z kredy bolońskiej mieszanych z zagęszczonym olejem lub gęstym werniksem damarowym. Autor zaznacza, że kit ten bardzo szybko twardnieje, ale jednocześnie poleca go do wyrównywania i umocowania drobnych czasstek warstwy malarskiej. Przypuszczalnie ideą jest tu naniesienie kitu, skutkujące nie tylko wypełnieniem ubytków, ale także częściowym pokryciem powierzchni malarskiej. Mimo tego, że transparentny kit uwidacznia leżące pod nim cząstki malowidła, należy pamiętać, że odwracalność kitu zawierającego olej schnący pogarsza się z czasem i usuwanie go może stanowić potencjalne zagrożenie dla leżącej pod spodem warstwy malarskiej. Ponadto taki sposób założenia kitu może powodować tuszowanie jej oryginalnej faktury. B. Slansky ${ }^{44}$ nie poleca stosowania kitu

w nim pędzli różnych farb, a przytem gęstnieje i tężeje. Zmieszany z trochą blejwajsu, i podług potrzeby z trochą skubanek, daje gęstą mase, która dobrze schnie, lecz według mego zdania za wolno twardnieje".

41 B. Slansky, Technika malarstwa, t. 2: Badanie, s. 241.

42 Ibidem.

43 M. Doerner, op. cit., s. 301.

44 B. Slansky, Technika malarstwa, t. 2: Badanie, s. 241. 
transparentnego z uwagi na silne żółknięcie i ciemnienie oleju w mieszaninie z barwnikami o słabej zdolności krycia. Odnotowuje także, że zastąpienie oleju gęstym werniksem żywicznym lub jego mieszaniną z woskiem, z powodu poważnych trudności w nakładaniu, nie zdało egzaminu.

Innym rodzajem kitu olejnego używanym w minionych stuleciach jest kit z bielą ołowiową ${ }^{45}$, który obecnie nastręcza konserwatorom wielu problemów. W wyniku chemicznej reakcji ołowiu ze schnącym olejem kit staje się znacznie twardszy niż kity olejne zawierające inne wypełniacze, co sprawia, że jest on niezwykle trudno usuwalny z obrazu ${ }^{46}$.

\section{Kity woskowe}

Kity woskowe zawierają wosk pszczeli jako spoiwo oraz wypełniacze i pigmenty. W wielu przypadkach do spoiwa jest także dodawana żywica naturalna: mastyks, damara lub terpentyna wenecka, a dawniej również kalafonia. K. Nicolaus ${ }^{47}$ na podstawie cytowanych przez siebie materiałów źródłowych uważa, że kit woskowy pojawił się w użyciu w XVIII wieku w wyniku badań enkaustyki; A. J. Pernety ${ }^{48}$ podaje, że powstał on w 1757 roku. W. Ślesiński ${ }^{49}$ odnotowuje, że w okresie 1800-1918 do uzupełniania ubytków zapraw stosowano oprócz olejnych także kity z wosku, terpentyny weneckiej i barwnika mineralnego. C. F. Prange ${ }^{50}$ wykorzystał maść woskową do wypełnie-

45 Dokładna nauka, s. 5-6, poleca grunt olejny do naprawy miejsc uszkodzonych na obrazach olejnych na płótnie, przyrządzony z dobrze utartej bieli ołowianej (blejwajsu) z olejem. Na s. 47 autor podaje dwa przepisy na kity służące do wypełniania rozstępów i pęknięć w warstwie malarskiej: pierwszy złożony z „miałkiego blejwajsu i pokostu lnianego, inny jeszcze robi się z blejwajsu, białego bolusu i nieco miniji, który jednak tylko do malowideł na drzewie służy".

46 K. Nicolaus, op. cit., s. 240.

47 Ibidem.

48 Ibidem, [za:] A. J. Pernety, Dictionnarie portratif de peinture, sculpture, et gravure, Paryż 1757. Niemiecka edycja: Des Herrn Pernety Handlexikon der bildenden Kunste [...], Berlin 1764, s. 498-499.

49 W. Ślesiński, Dawne metody, s. 27.

50 K. Nicolaus, op. cit., s. 240, [za:] C. F. Prange, Erfahrungen und Grundsatze uber die geheimnisvalde Kunst, alte Gemalde wiederherzustellen und zu erhalten, dodatek w: P. L. Bouvier, Handbuch der Olmalerei, Halle 1828, s. 484. 
nia zerwanych krakelur w 1828 roku, a w 1853 roku H. Deon ${ }^{51}$ wspomina o wosku i kitach woskowo-żywicznych.

Funkcje wypełniaczy, podobnie jak w przypadku innych rodzajów kitów, pełnią kreda szampańska, pławiona lub bolońska, z ewentualnym uzupełnieniem kolorowymi pigmentami. Wyjątkowo wypełniaczami są wyłącznie pigmenty. Taki właśnie kit, złożony ze stopionych razem: wosku, żywicy i suchych, kolorowych pigmentów, wzmiankuje E. W. Kudriawcew ${ }^{52}$. Twierdzi on, że kit ten sprawdza się szczególnie w płytkich ubytkach i przetarciach, wzmacniając je, a brak tendencji do pękania zawdzięcza swej wysokiej plastyczności.

Przygotowanie kitu woskowego polega na roztopieniu małej ilości żywicy w naczyniu umieszczonym na łaźni piaskowej, a następnie wosku aż do upłynnienia. Wówczas dodaje się wypełniacz i za pomocą szpachli lub łopatki zagniata do uzyskania pożądanej konsystencji, po czym kit formuje się w małe wałeczki i w takiej postaci pozostawia do wychłodzenia. Dzięki odpowiedniemu dozowaniu wypełniaczy możliwe jest otrzymanie kitu o zróżnicowanej konsystencji i stopniu twardości.

Stosunkowo miękkie kity zaleca się stosować w przypadku uzupełniania małych ubytków, które zostały pominięte w czasie wykonywania zasadniczego zabiegu, a także w przypadku uzupełniania małych ubytków leżących bardzo blisko siebie, gdy istnieje ryzyko nałożenia kitu z nadmiarem. Jeśli w dalszym postępowaniu jest przewidziane uzyskanie faktury za pomocą rozgrzanej formy, wówczas również wskazane jest użycie miękkiego kitu. Jego zaletą jest łatwość stosowania, gdyż plastyczność, pozwalającą na wciśnięcie go narzędziem w ubytek, można osiągnąć już poprzez ogrzewanie między opuszkami palców. Do typowych zadań związanych z uzupełnianiem ubytków zalecane jest użycie nieco twardszych kitów. Muszą być one zakładane za pomoca podgrzewanych lopatek, a nawet wtapiane bezpośrednio w ubytek końcówką rozgrzanego kautera. Prace przyspiesza i ułatwia też podgrzanie kitu w niewielkim metalowym naczyniu umieszczonym na łaźni wodnej i nakładanie go narzędziami dentystycznymi. Obróbka kitów - szczególnie na większej powierzchni uzupełnienia - jest czynnością dosyć uciążliwą,

51 Ibidem, [za:] H. Deon, De la conservation et la restauration des tableaux, Paryż 1851.

52 E. W. Kudriawcew, op. cit., s. 119. 
wymagającą doświadczenia i wprawy. Po wyrównaniu lub opracowaniu faktury pozostałości kitu usuwa się z zagłębień oryginalnej warstwy malarskiej zwitkiem bawełnianym zwilżonym benzyną lakową, a jeśli powierzchnia jest wrażliwa na rozpuszczalniki, suchą bawełnianą lub nylonową szmatką albo za pomocą skalpela. Do głównych zalet kitów woskowych należą przede wszystkim: odporność i trwałość w wilgotnym środowisku ${ }^{53}$, ponadto duża elastyczność, brak napięć podczas twardnienia i łatwość usuwania ${ }^{54}$. Jedną z ważniejszych zalet kitu woskowo-żywicznego jest też możliwość jednorazowego wypełniania nawet bardzo głębokich ubytków, gdyż niezawierający rozpuszczalników kit nie kurczy się wcale lub niemal niezauważalnie w fazie stygnięcia ${ }^{55}$. Kity woskowe, z racji dobrej przyczepności do przewoskowanego podłoża, były powszechnie stosowane w przypadkach, gdy wosk został uprzednio wprowadzony do obiektu.

Kit woskowo-żywiczny uzyskuje w pełni swą odporność i umocowanie w ubytku, kiedy jest wystudzony. W temperaturze pokojowej kit z dużym udziałem wypełniaczy i pigmentów jest twardy, mocny i łamliwy (kruchy), co w przypadku silnych ruchów podłoża płóciennego może skutkować pękaniem wypełnienia. Niskie temperatury (ok. $\left.0^{\circ} \mathrm{C}\right)$ nie są dla niego korzystne, gdyż traci odporność, następuje jego kruszenie i rozkład ${ }^{56}$. Za wade uważa się także ciemną barwę kitów woskowych ${ }^{57}$. Powodowanie przebarwień w chudych warstwach malarskich na skutek zmian współczynnika załamania światła sprawia, że kit woskowo-żywiczny nie jest odpowiedni do uzupełniania ubytków chudych gruntów klejowo-kredowych i warstw malarskich wykonanych w klejowych i temperowych technikach ${ }^{58}$. Nie jest również polecany do wypełniania rozległych ubytków w obrazach na podłożu płóciennym. W efekcie przesycenia struktury płótna przez zakładanie rozgrzanego kitu w nieizolowany uprzednio ubytek mogą powstawać przebarwienia pod-

53 B. Slansky, Technika malarstwa, t. 2: Badanie, s. 241.

54 W. Ślesiński, Konserwacja zabytków, s. 91.

55 K. Nicolaus, op. cit., s. 241.

56 A. Markowska, Materiały do konserwacji obrazów na płótnie eksponowanych w ekstremalnych warunkach, maszynopis pracy magisterskiej napisanej pod kier. prof. dr B. Rouby w ZKMiRP UMK, Toruń 1998.

57 K. Chmiel-Wajda, op. cit., s. 53.

58 K. Nicolaus, op. cit., s. 241. 
łoża płóciennego. Ponadto kity woskowo-żywiczno-kredowe są niekiedy widoczne na odwrociu obrazu jako płytkie wybrzuszenia ${ }^{59}$. B. Slansky ${ }^{60}$ wyraża opinię, że kit woskowy może być stosowany w pewnych okolicznościach do obrazów na deskach. Uważa też, że kit ten jest najbardziej odpowiedni pod retusz woskowy, podczas gdy pod inne rodzaje retuszy jego powierzchnia musi być odpowiednio przygotowana przez przetarcie żółcią wołową lub zaizolowanie alkoholowym roztworem białego szelaku ${ }^{61}$. Zabiegi te polepszają zwilżalność kitu przez wodne spoiwo farb i umożliwiają wykonanie punktowań. Jednakże badania przyczepności powłok retuszy wykazują, że ich adhezja do kitu woskowego jest niezadowalająca - i to zarówno uzupełnień akwarelowych, akrylowych, jak i olejnych ${ }^{62}$. Po upływie kilkunastu lat od konserwacji wszelkie uzupełnienia wykonane na kitach woskowych przejawiaja tendencje do pekania, ciemnienia, łuszczenia i odpadania w formie drobnych łusek lub tworzenia rozstępów w powłoce barwnej ${ }^{63}$. Do wad kitów woskowych należy też mięknienie i rozmywanie pod wpływem werniksów olejno-żywicznych. Jeśli w dodatku do wykonania barwnych uzupełnień użyje się farb woskowych z tub lub pigmentów mieszanych z terpentynową pastą woskową, werniks końcowy może być naniesiony jedynie za pomoca rozpylacza ${ }^{64}$.

W literaturze konserwatorskiej istnieją receptury, zawierające różnorodne proporcje różnych składników. Przykładowe mieszaniny są następujące $e^{65}$ :

1. wosk pszczeli + kreda (ewentualnie + pigment);

2. wosk pszczeli (3 cz.) + damara (1 cz.) + kreda;

59 Ibidem.

60 B. Slansky, Technika malarstwa, t. 2: Badanie, s. 237.

61 Ibidem, s. 241.

62 M. Wiciejowska-Stankiewicz, Kity w obrazach na płótnach przesyconych woskiem, praca magisterska wykonana pod kier. doc. Z. Wolniewicz w ZKZR UMK, Toruń 1978, s. $27-28$.

63 G. Patocka, Trwałość punktowań wykonanych farbami wodnymi na kitach woskowo-żywicznych w obrazach olejnych na płótnie, maszynopis pracy magisterskiej napisanej pod kier. doc. dr M. Roznerskiej w ZKMiRP UMK, Torun 1989, s. 26-28.

64 Ibidem, s. 13.

65 Przykłady 1-3 wg K. Nicolaus, op. cit., s. 241, przykład 4 wg W. Ślesińskiego, Konserwacja zabytków, s. 91, przykład 5 z pracy magisterskiej K. Chmiel-Wajdy, op. cit., s. 34. 
3. wosk pszczeli ( 3 cz.) + kalafonia (1 cz.) + terpentyna wenecka (1 cz.) + + kreda;

4. wosk pszczeli (1 cz. $)+$ kalafonia $(0,5$ cz. $)+$ terpentyna wenecka (1/10 cz.) + kreda (1 cz.);

5. wosk pszczeli $(3$ cz. $)+$ mastyks $(1$ cz. $)+$ terpentyna wenecka $(0,5$ cz. $)+$ + kreda pławiona lub pigment (3 cz.).

Kalafonia, wymieniana w recepturach i stosowana niegdyś w kitach, obecnie nie jest polecana ze względu na jej wysoką kwasowość (liczba kwasowa 150-180), która destrukcyjnie wpływa na celulozę w płótnie. Ponadto żywica ta nie jest odporna na wilgoć, a przy tym jest krucha.

Podobnie jak w przypadku kitu olejnego, możliwe jest sporządzenie transparentnego kitu woskowego, którego użycie jest polecane w wyjątkowych sytuacjach. We wszystkich przypadkach, gdy wyrównanie powierzchni za pomocą kitu nie jest możliwe bez czesściowego pokrycia oryginalnego malowidła, proponuje się zastosowanie jednego z dwóch przezroczystych woskowych kitów: pierwszego, wykonanego z białego wosku pszczelego (cera alba) i żywicy damarowej, lub drugiego, z wosku mikrokrystalicznego z żywicami syntetycznymi, takimi jak Lascaux Adhesive Wax 443-95 ${ }^{66}$.

\subsection{Kity oparte na spoiwach syntetycznych}

\section{Kit na bazie BEVA $371^{67}$}

Termoplastyczne spoiwo BEVA 371 znalazło szerokie zastosowanie w praktyce konserwatorskiej od początku lat 70. XX wieku, gdy zaczeły ukazywać się raporty na jego temat ${ }^{68}$. Spoiwem kitu jest BEVA 371, zawierająca mieszaninę syntetycznych żywic i parafinę rozpuszczone w toluenie i benzynie ekstrakcyjnej, a wypełniaczem kreda szampańska, pławiona lub bolońska i ewentualnie pigmenty. BEVA-kit jest przyrządzany przez mieszanie razem

66 K. Nicolaus, op. cit., s. 242.

67 BEVA 371 - (Berger ethylene vinyl acetate) - spoiwo opracowane przez Gustawa Bergera o następującym składzie: octan winylowo-etylenowy [Elvax 150], żywica policykloheksanowa [Keton N], ester kwasu ftalowego [Cellolyn 21], parafina; stanowiące 40\% roztwór w toluenie i benzynie o frakcji 80/120 [odpowiednik naszej benzyny ekstrakcyjnej].

68 I. Szmelter, Problemy dublowania obrazów na podłożu płóciennym, „Zeszyty Naukowe Akademii Sztuk Pięknych w Warszawie”, Warszawa 1992, s. 49. 
spoiwa i wypełniaczy - do konsystencji pasty lub zwartej szpachlówki. Generalnie kit ten należy do kitów syntetycznych woskowo-żywicznych. Kity z BEVA 371 i kredy wykazują elastyczność, odporność na wilgoć, adhezję do płótna i odwracalność zbliżone do kitów woskowo-żywicznych, opartych na materiałach naturalnych. $Z$ powodu tworzenia jednolitej ciagłej błony powierzchnie kitów są trudne do opracowania i wygładzenia po wyschnięciu, dlatego zaleca się ich opracowywanie w trakcie wysychania lub nawet tuż po założeniu kitu w ubytek ${ }^{69}$.

Szwajcarska firma Lascaux, produkująca licencyjny preparat, w informacji firmowej ${ }^{70}$ podaje recepturę kitu, składającą się z 1 cześci BEVA 371 (w rozcieńczeniu z benzyną ekstrakcyjną 1:4) i 2 czesści kredy lub pigmentu. W 1978 roku kit o takim składzie został poddany badaniom w ramach pracy magisterskiej przez M. Wiciejowską-Stankiewicz ${ }^{71}$, szukającą alternatywy dla kitu woskowego. Autorka stwierdziła podobieństwa obu kitów pod względem niskiej chłonności i zwilżalności, przy jednoczesnej lepszej adhezji retuszy akwarelowych, akrylowych, a zwłaszcza olejnych do kitu na bazie BEVA. Kit, wysychając, tworzy dość gładką powierzchnię, dającą się doszlifować po całkowitym wyschnięciu za pomocą skalpela, natomiast wykonanie faktury z użyciem ostrego narzędzia jest łatwiejsze w lekko podeschniętym wypełnieniu. $Z$ uwagi na to, że zmywanie punktowań benzyną lakowa, powodująca rozmywanie kitu, jest kłopotliwe, proponuje zastosowanie 15\% Paraloidu w toluenie jako warstwy izolacyjnej, zmniejszającej nieco to niebezpieczeństwo. Porównując kit BEVA-kredowy z emulsyjnym „wiedeńskim" pod względem zbliżonej elastyczności oraz sposobu nakładania i opracowywania, autorka w końcowej konkluzji stwierdza jednak, że kit na bazie $B E V A$ ustępuje miejsca drugiemu ${ }^{72}$. Mimo skoncentrowania uwagi na podłożach płóciennych przesyconych masą woskowo-żywiczną autorka nie wykonała, narzucającego się tu, badania adhezji do płótna.

69 A. G. Berger, Formulating Adhesives for Conservation of Painting, [w:] Conservation and Restoration of Pictoral Art, London-Boston 1978, s. 169-172; K. Nicolaus, op. cit., s. 242.

70 Lascaux-report. Herausgegeben von Alois K. Diethelm, Farbenfabrikation, CH-8306 Bruttisellen, R6/1977.

71 M. Wiciejowska-Stankiewicz, op. cit.

72 Ibidem, s. 28-29. 
Kit na bazie BEVA 371 lub, bardziej precyzyjnie, BEVA-kredowy może być stosowany w jednej lub większej ilości warstw do wyrównania z poziomem warstwy malarskiej, a następnie wygładzany za pomocą szpachelki (ułatwieniem może być położenie na kit arkusza papieru silikonowanego). Kit przygotowany z 1 części BEVA 371 i 2 części kredy szampańskiej jest przydatny do pracy przez około 20 minut, po czym następuje jego żelowanie, a po około 8 godzinach staje się on suchy. W przypadku rozległych uszkodzeń może to stanowić pewne utrudnienie w pracy, która musi przebiegać szybko i sprawnie. Badający tę mieszaninę K. Nicolaus ${ }^{73}$ poleca w takiej sytuacji ułatwienie, polegające na zastosowaniu zwartej szpachlówki, przygotowanej podobnie jak kit woskowy; świeżą masę uformowaną w małe wałeczki pozostawia się do wyschnięcia i wprowadza w ubytki po rozgrzaniu kauterem. Także wygładzenie i opracowanie faktury kitu wykonuje się z użyciem rozgrzanego narzędzia. Zwiększenie ilości kredy do 3 cześci daje kit trudny do wymieszania, zakładania i opracowywania, mający po wyschnięciu dobra adhezje, ale twardy i z drobnymi spekaniami ${ }^{74}$.

Kit o zmodyfikowanym składzie, zawierający 20\% BEVA $371 \mathrm{w}$ benzynie lakowej, 20\% Paraloid B-72 w toluenie i krede w stosunku wagowym 1:1:2, został przebadany w ramach dwóch prac magisterskich, powstałych wZKMiRP UMK w Toruniu. W obu pracach testowano kity pod katem przydatności do uzupełniania ubytków zapraw na podobraziach metalowych. E. Kuśnierz ${ }^{75}$ przeprowadziła badania porównawcze kitów o różnych rodzajach spoiwa (klejowe, emulsyjne, woskowo-żywiczne, olejne i rozpuszczalnikowe). Autorka w tym kontekście najwyżej ocenia kit rozpuszczalnikowy na bazie BEVA 371 i Paraloidu B-72, ze względu na odporność na działanie wilgoci, elastyczność w różnych warunkach klimatycznych, dobrą przyczepność retuszy do powierzchni kitu - mimo słabej zwilżalności i chłonności przez wodne spoiwo farb. Podkreśla korzystny wpływ Paraloidu B-72 na poprawienie adhezji kitu do metalu i zapewnienie odpowiedniej porowatości,

73 K. Nicolaus, op. cit., s. 242.

74 J. Green, J. Seddon, op. cit., s. 81/2/12-4-81/2/12-5.

75 E. Kuśnierz, Materiały służące do uzupełniania ubytków zaprawy i warstw malarskich w obrazach na podobraziach metalowych, maszynopis pracy magisterskiej napisanej pod kier. doc. dr M. Roznerskiej w ZKMiRP UMK, Toruń 1986. 
jakiej nie ma kit, w którym zastosowano jako spoiwo wyłącznie BEVA $371^{76}$. Kontynuujący badania P. Romanowski ${ }^{77}$, porównując właściwości obu wariantów kitów, potwierdził wysoką ocenę wystawioną przez Kuśnierz masie zawierającej BEVA 371 i Paraloid B-72. Zauważył też, że w przypadku bardzo cienkich warstw malarskich konieczny jest dobór wypełniacza o bardzo drobnej czasteczce, jakim jest np. kreda pławiona ${ }^{78}$.

Przed kilkunastu laty pojawily się w handlu gotowe kity na bazie BEVA 371 o nazwie BEVA® Gesso-P i BEVA® Gesso- $V$, produkowane w dwóch wariantach o zróżnicowanej granulacji wypełniacza (CPC Conservator's Products Company - USA).

\section{Kity na polialkoholu winylu}

Polialkohol winylowy został otrzymany po raz pierwszy w 1924 roku w wyniku hydrolizy polioctanu winylu, a jego produkcja na większą skalę rozpoczęła się w 1931 roku. Pierwsze próby zastosowania polialkoholu winylu w malarstwie i konserwacji zabytków zostały podjęte w latach 50 . XX wie$\mathrm{ku}^{79}$, a dokładniej - od 1953 roku w Katedrze Technologii i Technik Malarskich UMK w Toruniu ${ }^{80}$. Na tej podstawie można przyjać, że w tym czasie zaczęto też używać polialkoholu winylu jako spoiwa do kitów w konserwacji malarstwa sztalugowego.

Kity te są utworzone z polialkoholu winylu (PAW), będącego w nich spoiwem, i kredy szampańskiej, pławionej lub bolońskiej, pełniących funkcję wypełniaczy, które w razie potrzeby mogą być uzupełniane barwiącymi pigmentami. Leonard Torwirt ${ }^{81}$ polecał kit otrzymany przez zagniatanie ze spoiwem czystej kredy pławionej ze względu na jego elastyczność, łatwość

76 Ibidem, s. 82.

77 P. Romanowski, Konserwacja dwóch obrazów olejnych na podobraziu miedzianym. Problem kitowania i punktowania cienkich warstw malarskich, praca magisterska napisana pod kier. doc. dr M. Roznerskiej w ZKMiRP UMK, Toruń 1989.

78 Ibidem, s. 40, 44

79 J. Ciabach, Żywice i tworzywa sztuczne stosowane w konserwacji zabytków, Toruń 1998, s. 96, 101.

80 L. Torwirt, Zastosowanie polialkoholu winylu $w$ malarstwie $i$ konserwacji zabytków, „Ochrona Zabytków”, 1961, nr 1-2, s. 71.

81 Ibidem, s. 74. 
wyrównywania, brak spękań i dobrą adhezję do podłoża. Autor zaleca dodatek gliceryny w celu zwiększenia elastyczności i regulowania porowatości wypełnienia. Ubocznym, niepożądanym skutkiem obecności tej substancji jest wzrost higroskopijności polialkoholu winylu, co przy jego niewielkiej odporności na atak mikroorganizmów obniża ją jeszcze bardziej ${ }^{82}$, zwiększając ryzyko zakażenia, i praktycznie wyklucza stosowanie tego plastyfikatora. Poliglikole etylenowe o masie cząsteczkowej do 1000 j.m.a. są pod tym względem nieco lepsze ${ }^{83}$.

W 1976 roku w Centralnym Laboratorium Badawczym Obiektów Sztuki i Nauki w Amsterdamie przeprowadzono porównawcze badania organicznych i syntetycznych żywic, które mogłyby być użyte jako spoiwa do kitów. Uczestnicząca w tych badaniach i kontynuująca je D. Falvey ${ }^{84}$ przetestowała kit na bazie polialkoholu winylu. Szczególnie polecany przez autorkę do wykonywania kitów jest produkt o firmowej nazwie Mowiol ${ }^{85}$. Przebadała ona kit kredowy (z dwukrotnie strącaną kredą) na Mowiolu 04-Ml ze sporym sukcesem. Oceniła, że ma on znakomite właściwości związane z aplikacją (konsystencje, łatwość użycia, modelowania), dobrą adhezję - zarówno do czystego nieprzeklejonego płótna, jak i do płótna przewoskowanego, szybko wysycha bez widocznego skurczu i może być łatwo usuwalny za pomoca wody oraz skalpela z powierzchni warstwy malarskiej. Także wyniki trwającego 12 miesięcy naturalnego starzenia kitów (przez 6 pierwszych miesięcy kity występowały w czystej postaci, a przez pozostałe 6 miesięcy były pokryte retuszami o spoiwie olejnym i wodnym) okazały się bardzo obiecujące; kity nie pociemniały, nie pożółkły, jak również nie spowodowały zmian koloru żadnej z formuł malarskich.

Z kolei I. Sandner ${ }^{86}$, uznając polialkohol winylu za spoiwo odpowiednie do kitów, uważa, że są one szczególnie przydatne do uzupełniania ubyt-

82 J. Ciabach, Właściwości i zastosowanie polialkoholu winylu, „Ochrona Zabytków”, 1984 , nr 1, s. 49-50.

83 Idem, Żywice i tworzywa sztuczne, s. 100.

84 D. M. Falvey, op. cit., s. 81/2/13-6.

85 Mowiol 04-Ml, produkt niemieckiej firmy Hoechst AG, jest wewnetrznie plastyfikowanym kopolimerem polialkoholu winylu z małą ilością polioctanu winylu.

86 I. Sandner, op. cit., s. 6-5. 
ków zapraw na podobraziach drewnianych. Zapewne tego typu opinie miały wpływ na dalsze badania i rozszerzanie zastosowania kitów na polialkoholu winylu w takich dziedzinach, jak np. konserwacja pozłotnictwa. Stosujący ten kit w praktyce z dobrymi rezultatami J. Thornton ${ }^{87}$ twierdzi, że jego zaletami są przede wszystkim stabilność chemiczna, dobre i łatwe do zmodyfikowania właściwości związane z opracowywaniem, porowatość porównywalna z porowatością gruntów sporządzonych na bazie kleju zwierzęcego, a także odwracalność w niektórych organicznych rozpuszczalnikach, takich jak alkohole. Do sporządzania kitów poleca stosowanie polialkoholu winylu o wysokim ciężarze cząsteczkowym w stężeniach pomiędzy 4\% a 8\%. Kit po zmieszaniu z kredą powinien mieć konsystencję gęstej szpachlówki. W wyniku użycia spoiwa o niższym stężeniu kit będzie bardziej miękki oraz łatwiejszy do wygładzenia i wyrównania, natomiast zastosowanie wyżej stężonego spoiwa da twardszy kit, który jest bardziej odpowiedni do narażonych na urazy krawędzi obiektu. Brak zdolności żelowania polialkoholu winylu może, w opinii J. Thorntona, stanowić utrudnienie w nakładaniu kolejnych warstw kitu za pomoca pędzla. Zauważa także, że szlifowanie warstw naniesionych pędzlem może dawać efekt nierówności powierzchni (przebiega nierównomiernie) i przypisuje to osiadaniu i warstwowemu oddzielaniu się kredy w płynnym nieżelującym środowisku. Pożyteczną cechą kitu na bazie polialkoholu winylu jest jego płynność przy równoczesnej niskiej lepkości, co umożliwia wstępne uzyskanie płaskiej i gładkiej powierzchni płytkich ubytków przez delikatne tepowanie opuszkami palców wilgotnego jeszcze kitu. Autor proponuje dodatek siarczanu baru (bieli barytowej) w celu uczynienia kitu bardziej nieprzezroczystym. Po wyschnięciu daje się on łatwo wyrównywać i wygładzać z użyciem zwilżonej wodą lub alkoholem szmatki, korka, palca lub za pomocą narzędzia.

Michel Hebrard i Sophie Small ${ }^{88}$, w ramach eksperymentów z zastosowaniem polialkoholu winylu jako substytutu klejów glutynowych w konserwacji złoconego drewna, przebadali także kity oparte na tym spoiwie. Do ba-

87 J. Thornton, The use of nontraditional methods and materials in conservation, [w:] Gilded Wood. Conservation and History, Madison Connecticut 1991, s. 220-221.

88 M. Hebrard, S. Small, Eksperiments in the use of Polivinyl Alkohol as a substitute for Animal Glues in the Conservation of Gilded Wood, [w:] Gilded Wood, s. 286-287. 
dań zostały użyte produkty firmowe o nazwie Rhodoviol ${ }^{89}$ o różnym ciężarze cząsteczkowym. Autorzy, przeciwnie niż wyżej wzmiankowany J. Thornton, stwierdzają, że najbardziej przydatne są polialkohole o niskim ciężarze cząsteczkowym, dające kity, które wysychają bez widocznego skurczu i spękań. Najwłaściwsze stężenie spoiwa w stosunku do wody to według M. Hebrard i S. Small 1:10, które daje kity bardzo łatwe do opracowania zarówno na sucho, jak i na mokro, a ich powierzchnia po szlifowaniu jest bardzo bliska tradycyjnemu gruntowi, a nawet gładsza. Wyższe stężenia spoiwa ( $1: 6$ z wodą) powoduja, że kit staje się odrobinę za twardy i trudno jest go opracować na sucho bez zwilżenia powierzchni wodą. Autorzy, badając odwracalność kitów po 12 miesiącach naturalnego starzenia, wykazali, że Rhodoviol z wypełniaczem jest bardziej miękki niż kit, w którym spoiwem jest klej króliczy; łatwiej go usunąć zarówno mechanicznie, jak i po zastosowaniu okładów z alkoholu etylowego, podczas gdy kitów na bazie kleju glutynowego alkohol nie rozmiękczał. Badacze sugeruja, aby wybierać nisko zhydrolizowane gatunki polialkoholu winylu ze względu na ich zdolność do rozpuszczania się w niskich temperaturach i małą wrażliwość na wahania wilgotności. Radzą także stosować produkty o niskiej masie cząsteczkowej (nisko spolimeryzowane), które pozwolą uniknąć roztworów zbyt lepkich, trudnych do przygotowania lub wymagających podgrzania.

\section{Kity na polioctanie winylu}

Kity te zawieraja dyspersje polioctanu winylu jako spoiwo i krede szampańską, pławioną lub bolońską jako wypełniacz, ewentualnie pigmenty do podbarwienia.

Heinz Althofer ${ }^{90}$ badał Ponal - spoiwo oparte na polioctanie winylu w mieszaninie z kredą szampańską w stosunku 1:2. Mieszanina tworzy kit łatwy do aplikowania i obróbki, który jednakże jest nieodwracalny, kruchy i trudny do szlifowania. Podobnie niepochlebną opinie, na podstawie praktyki i badań prowadzonych w Akademii Sztuk Pięknych w Dreźnie, wyraża

89 Polialkohol winylu - Rhodoviol produkowany przez Rhone-Poluenc, Francja.

90 H. Althofer, Restaurierung moderner Malerei. Tendenzen - Material - Technik, Munich 1985, s. 110. 
I. Sandner ${ }^{91}$. Twierdzi on, że wypełnienia, w których spoiwem jest dyspersja polioctanu winylu, okazują się szczególnie niekorzystne w przypadku umieszczenia obiektu w atmosferze o stałej wysokiej wilgotności, co powoduje pękanie i zmiany wytrzymałości wypełnienia. Kazimiera Chmiel-Wajda, badając kredowy kit sporządzony z 15\% polioctanu winylu z dodatkiem polialkoholu winylu ${ }^{92}$, oceniła, że wysokie stężenie spoiwa sprawia, iż kit jest bardzo trudny w nanoszeniu i obróbce (szybko gęstnieje i twardnieje), bardzo twardy po wyschnięciu i jako taki nie może być stosowany do obrazów, gdyż powoduje deformacje powierzchni i odrywanie się sąsiadujących z nim kruchych warstw malarskich ${ }^{93}$. Autorka nie badała kitów sporządzonych na bazie polioctanu winylu o niższym stężeniu.

W grupie 30 preparatów przetestowanych przez J. Green i J. Seddon ${ }^{94}$, obok kitów klejowych, emulsyjnych, poliakrylowych i na bazie BEVA 371, sporządzonych zarówno z materiałów naturalnych, jak i syntetycznych i ich mieszanin, znalazły się cztery masy oparte na emulsji polioctanu winylu (Instant Polyfilla, Fine Surface Polyfilla, Sealobond, Mowilith DM5) z kreda. Jeden z kitów, na bazie Fine Surface Polyfilla, znalazł się pośród pięciu materiałów, które autorzy ocenili najwyżej, biorąc pod uwagę możliwości odwzorowania faktury (odciski z form), minimalny skurcz, dobrą adhezję i elastyczność. Pozostałe trzy kity polioctanowe mimo dobrej adhezji i odpowiedniej twardości miały większy skurcz (25-40\% w stosunku do pierwotnej grubości), który uniemożliwiał uzyskanie właściwej faktury metodą odciskania z formy. Także, oprócz kitu na bazie Instant Polyfilla, dwie pozostałe masy oceniono jako trudne w pracy i aplikowaniu (jedną - z powodu nadmiernej płynności i lepkości, drugą - z racji trudności z mieszaniem i szybkości wysychania). Autorzy nie prowadzili analiz starzeniowych materiałów. Wyżej przytoczone wyniki badań najlepiej obrazuja zależność ostatecznych właściwości kitu od jakości spoiwa.

91 I. Sandner, op. cit., s. 6-5.

92 K. Chmiel-Wajda, op. cit., s. 33; dokładna receptura: 10 cz. 15\% POW + 3 cz. 15\% PAW +3 cz. kredy pławionej.

93 Ibidem, s. 46, 53.

94 J. Green, J. Seddon, op. cit., s. 81/2/12-4-81/2/12-5, 81/2/12-8. 


\section{Kity poliakrylowe}

Kity poliakrylowe zawierają dyspersje żywic akrylowych lub ich roztwory rozpuszczalnikowe i wypełniacze (kredę szampańską, pławioną lub bolońską) i ewentualnie pigmenty. Żywice akrylowe są uzyskiwane przez polimeryzację kwasów akrylowych i ich estrów. Jako spoiwo kitów są szczególnie polecane na podłoża płócienne przez I. Sandnera ${ }^{95}$. Stwierdza on, że powierzchnie konserwowane z użyciem tego rodzaju żywic są przepuszczalne dla par, zachowują elastyczność i dostosowują się do wszystkich ruchów płótna. Także adhezja kitów do gruntu malarskiego jest znakomita, nie mają one wewnętrznych naprężen, a ich powierzchnia jest odporna na zarysowania. W zależności od zastosowanych typów żywic akrylowych, takie wypełnienia są rozpuszczalne w toluenie, dichloroetanie, benzynie lakowej lub wyjątkowo także w alkoholu. Kity te są bardzo łatwe w obróbce. Spośród przebadanych w laboratorium badawczym Akademii Sztuk Pięknych w Dreźnie kitów, dyspersja akrylowa Schkopau D311 w mieszaninie z kredą rugijską lub szampańską i pigmentami oraz 4\% dodatkiem aerożelu silikonowego (silica aerogel $\mathrm{SiO}_{2}$ ) według autora dała zadowalające rezultaty ${ }^{96}$. W testach starzeniowych tego kitu z naniesionym akrylowym retuszem barwnym nie stwierdzono żadnych zmian - zarówno w samym kicie, jak i w powłoce retuszu.

Diane Falvey ${ }^{97}$, która badała między innymi Plextol B500 ${ }^{98}$ jako spoiwo do kitów, oceniła, że ma on znakomite właściwości związane z aplikacją, dobrą konsystencję oraz adhezję do płótna przewoskowanego i nieprzeklejonego, nawet w grubych warstwach wysycha bez widocznego skurczu i spękań. Testy starzeniowe trwające 12 miesięcy w warunkach laboratoryjnych nie wykazały żadnych zmian kitów ani naniesionych na nie powłok malarskich. Kit kredowy na bazie Plextolu B500 został również pozytywnie oceniony w niezależnych badaniach przeprowadzonych przez J. Green i J. Seddon ${ }^{99}$,

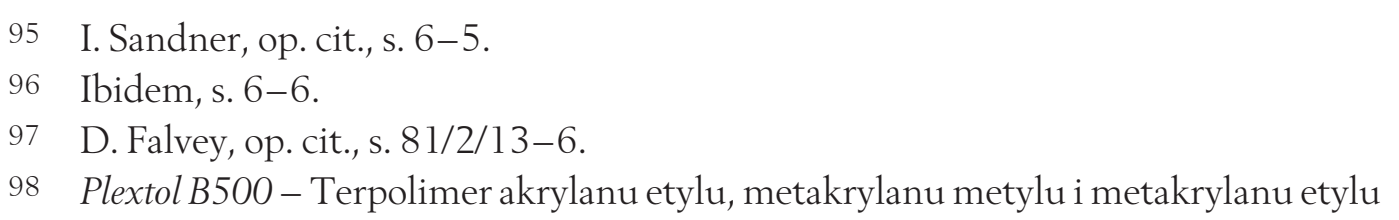
prod. Roehm GmbH (RFN).

99 J. Green, J. Seddon, op. cit., s. 81/2/12-8. 
którzy - poza dobrą elastycznością i adhezją oraz minimalnym skurczem tego kitu - zauważyli też jego zdolność do dobrego odwzorowania faktury przez odciskanie w formie. Podobnie, pod kątem właściwości i przydatności do odwzorowania faktury na kitach, zostały przebadane gotowe preparaty firmowe oparte na dyspersjach żywic akrylowych przez D. Nowacką ${ }^{100} \mathrm{w}$ ramach pracy magisterskiej. Autorka badała Lascaux Plastikmasse A i B (Lascaux-Restauro), Modeling Paste i Gesso (Talens), stwierdzając przydatność wszystkich materiałów do uzupełniania ubytków zapraw w malowidłach sztalugowych ze względu na ich dobrą elastyczność, minimalną higroskopijność, kurczliwość oraz rozszerzalność, a także odporność na wahania wilgotności względnej powietrza. Wadą wszystkich potencjalnych wypełnień jest całkowita niechłonność i niezwilżalność przez wodne spoiwo retuszu, którą redukuje użycie żółci wołowej. Przyczepność retuszy do powierzchni kitów autorka określa jako bardzo dobrą ${ }^{101}$. Ocenia też, że materiały te, pod kątem podatności i łatwości imitowania faktur przez modelowanie narzędziami i odciskanie w formach, przewyższają kity klejowe, emulsyjne i woskowo-żywiczne ${ }^{102}$.

Niejako potwierdzeniem dobrej oceny, wystawionej przez autorkę kitom poliakrylowym, jest przykład zastosowania jednego z badanych przez nią materiałów w spektakularnej realizacji w pierwszej połowie lat 90. XX wieku. Kit sporządzony na bazie Lascaux Plastik A, zmodyfikowany kredą, damarą i metylocelulozą, posłużył do uzupełnienia ubytków zaprawy w panoramie Arpada Fesztyego Wejście Wegrów. Według autorów konserwacji tak przygotowany kit dał wypełnienie odpowiednio elastyczne, mające właściwą kohezję, a także adhezję do oczyszczonego z nadmiarów masy woskowo-żywicznej płótna oryginalnego, dające możliwość opracowania za pomocą skalpeli oraz wymodelowania faktury impastów ${ }^{103}$.

100 D. Nowacka, Problematyka opracowywania faktur w kitach stosowanych do uzupełnień ubytków malowideł sztalugowych, praca magisterska wykonana pod kier. doc. dr M. Roznerskiej w ZKMiRP UMK, Torun 1986.

101 Ibidem, s. 77-79.

102 Ibidem, s. 95.

103 R. Wójtowicz, Konserwacja, restauracja i rekonstrukcja Panoramy Arpada Fesztyego „Wejście Wegrów”, „Ochrona Zabytków”, 1996, nr 2, s. 271. 


\section{Metody stosowane do uzupełniania i opracowywania ubytków zapraw}

\subsection{Przygotowanie ubytków}

Przed przystąpieniem do uzupełniania ubytków uszkodzona powierzchnia musi być odpowiednio przygotowana, a sposób i zakres przygotowania są uzależnione od kondycji obrazu i charakteru zniszczeń. Czynnością niezbędną jest oczyszczenie ubytków z brudu, wtórnych substancji i usunięcie kitów pochodzących z poprzednich ingerencji, jeśli zachodzą na warstwę malarską, różnią się fakturą czy mają odmienną siatkę spękań. Wszelkie prace związane z przywróceniem integralności rozluźnionych partii warstw gruntu i malarskich, reperacje lokalne podobrazia również należy przeprowadzić przed przystapieniem do uzupełniania ubytków.

Niekiedy w następnej kolejności proponuje się wykonanie izolacji uszkodzonego obszaru - zwłaszcza w przypadku rozległych ubytków - ale izolacji rozumianej przeciwnie niż „oddzielenie” i „odseparowanie”, będące podstawowym znaczeniem tego określenia. Izolacja lub materiały izolujące powinny w tej sytuacji umożliwić „kontakt adhezyjny” między dwoma materiałami: podłożem i kitem, powinny zapewniać możliwie dobre i ścisłe przylgnięcie kitu do ubytku. Substancje poprawiające adhezje to np. słabe roztwory kleju glutynowego (zmieszane ze środkiem powierzchniowo czynnym) ${ }^{104}$, środki zwilżające ${ }^{105}$ (zmniejszające napięcie powierzchniowe), żółć wołowa, a dawniej także sok czosnkowy, szelak w alkoholu (polecany w przypadku obrazów lub ubytków, które będą traktowane substancjami woskowo-żywicznymi). Środki adhezyjne mogą okazać się potrzebne przy stosowaniu kitów o wodnym spoiwie wiążącym. Przy podejmowaniu decyzji o użyciu

104 B. Slansky, Technika malarstwa, t. 2: Badanie, s. 238; autor poleca 5\% wodny roztwór kleju glutynowego z dodatkiem ałunu; W. Ślesiński, Konserwacja zabytków, s. 90; autor poleca kilkakrotne przeklejanie 3-5\% wodą klejową z ewentualnym dodatkiem ałunu.

105 K. Nicolaus, op. cit., s. 234; autor wymienia następujące środki zwilżające: etanol (szczególnie efektywny z klejem glutynowym); syntetyczny Agepon (stosowany do mycia filmów fotograficznych i w konserwacji malarstwa) zawierający mieszanke jonowych i niejonowych środków powierzchniowo czynnych, w stężeniu 0,5\% w stosunku do gotowego produktu; Surfynol 61 (niejonowy środek, który zgodnie z informacją producenta odparowuje bez śladu). 
środka adhezyjnego należy jednak mieć na uwadze fakt, że stosowanie go lokalnie, wyłącznie w partiach odsłoniętego płótna, może wpłynąć na nierównomierna prace podobrazia. $Z$ reguły dobrze przygotowany i odpowiednio sklejony kit, zaaplikowany w pozbawiony zanieczyszczeń i tłustych warstw ubytek, nie powinien nastręczać problemów z adhezją do podłoża. W przypadku, gdy masy takie będą zakładane na płótno przesycone wodoodporną substancją (np. masą woskowo-żywiczną), konieczne będzie wyekstrahowanie jej nadmiarów i odtłuszczenie odpowiednim rozpuszczalnikiem. Kit może być aplikowany w ubytki dopiero po zupełnym wyschnięciu środka adhezyjnego.

\subsection{Aplikowanie kitów}

W zależności od konsystencji kitu, wielkości i głębokości ubytku, masa do uzupełniania może być zakładana w jednej lub kilku warstwach, za pomocą różnorodnych narzędzi. Jak podaje literatura ${ }^{106}$, dawni restauratorzy malarstwa do zakładania kitów używali noża lub szpachelki malarskiej. Narzędzia te pozwalały, co prawda, pracować szybko, ale zarazem niedokładnie. Wiele obrazów, będących w ponownej konserwacji, pokazuje, że zabieg ten był wykonywany bez zatroszczenia się o zabytkową substancje: kity były zakładane z nadmiarem - nie tylko wypełniały ubytki, ale także pokrywały sąsiadujące z nimi, nierzadko znaczne, partie warstwy malarskiej. Obecnie konserwatorzy używaja, dobranych pod kątem potrzeb konserwatorskich, narzędzi dentystycznych, szpachelek lub specjalistycznych łopatek, które dają możliwości precyzyjnego aplikowania kitu w ubytki o wszelakim charakterze. Do zakładania kitów o płynnej konsystencji są też często stosowane pędzle, natomiast w przypadku kitów termoplastycznych używa się elektrycznie podgrzewanych narzędzi z wymiennymi końcówkami (kauterów). Polecane niekiedy aplikowanie gęstego kitu w ubytki za pomoca palca wydaje sie - w zestawieniu z możliwościami, jakie dają wymienione narzędzia - zbyt mało precyzyjnym sposobem.

106 Ibidem, s. 243, [za:] C. Wagner, Arbeitsweisen und Anschauungen in der Gemälderestaurierung um 1800. Dissertation, Munich 1988, s. 48. 
Płytkie ubytki mogą być uzupełnione jednorazowo, szczególnie gdy kit ma niewielki skurcz. W przypadku głębokich i rozległych uszkodzeń, a także wówczas, gdy kit ma pewien skurcz, konieczne jest kilkakrotne nanoszenie masy. Przy wielowarstwowym budowaniu wypełnienia muszą być zachowane pewne rygory. Zanim kolejna warstwa zostanie założona, praktycznie każda poprzednia powinna być sucha. Zapobiegnie to rozmywaniu się warstw spodnich, a także ich pękaniu. Pracując precyzyjnie i systematycznie, można dokładnie dopasować kit w ubytek, nie powodując przy tym zbędnego zanieczyszczenia warstwy malarskiej. Zasadniczo kit zakłada się z pewnym niewielkim nadmiarem, który następnie ostrożnie usuwa się z warstwy malarskiej. Ten sposób pracy narzuca konieczność zabezpieczenia krawędzi ubytków przed rozpoczęciem kitowania. Dotyczy to zwłaszcza spękanej, chropowatej powierzchni, gdyż drobiny sklejonego wypełniacza pozostające w strukturze warstwy malarskiej wywołują efekt szarej mgiełki, której doczyszczenie bez zastosowania warstwy izolacyjnej może być niezwykle trudne. Do tego celu najcześciej poleca się stosowanie łatwego do usunięcia werniksu damarowego, który po opracowaniu powierzchni kitu zmywa się wraz z pozostałościami pyłu tamponikiem waty nasączonym benzyną lakową (przy założeniu, że werniks nie pozostaje na powierzchni zbyt długo - jeśli zabieg się przedłuża, konieczne będą bardziej polarne rozpuszczalniki).

Niewłaściwą metodą uzupełniania ubytków jest szpachlowanie całego lub dużych partii obrazu rzadkim kitem, który po wyschnięciu jest zmywany z zanieczyszczonej warstwy malarskiej. Sposób taki może być przyczyną licznych problemów - począwszy od czaso-i pracochłonnego doczyszczania, aż do powodowania spękań warstwy malarskiej, założonego kitu oraz deformacji płótna na skutek wprowadzania wilgoci przy doczyszczaniu.

Niekiedy nietypowe zniszczenia wykluczają możliwość stosowania tradycyjnych metod uzupełniania ubytków. Do sytuacji takich może dochodzić w przypadku braku zaprawy lub wystepowania bardzo cienkiej warstwy malarskiej. Metode uzupełniania ubytków na potrzeby tego typu obrazów opracowała K. Rachuta ${ }^{107}$. Autorka, mając do czynienia z siatką mikroskopijnych ubytków warstwy malarskiej, zastosowała spoiwo BEVA 371 naniesione fa-

107 K. Rachuta, Problemy uzupełnień ubytków w cienkiej warstwie malarskiej na przykładzie obrazu „Matka Boska Gidelska”, „Ochrona Zabytków”, 1990, nr 3, s. 149-152. 
brycznie na folię, którą laminowała obraz na stole próżniowym w temperaturze $65^{\circ} \mathrm{C}$, uzyskując cienki, przezroczysty film, precyzyjnie wypełniający wszystkie ubytki. W ten sposób uniknięto konieczności szlifowania wypełnień i uzyskano podłoże pod barwne uzupełnienia. Modyfikując tę metodę, B. Rouba i J. Dudała ${ }^{108}$ wypełniły ubytki w dwustronnie malowanych choragwiach procesyjnych. Autorki nanosiły BEVA 371 wałkiem na awers i rewers choragwi oraz dodatkowo pedzlem w ubytki. W tym przypadku BEVA 371 pełniła jednocześnie funkcje spoiwa konsolidującego, kitu i masy dublażowej. Zabiegi zostały wykonane na stole próżniowym.

Innym rozwiązaniem, w przypadku bardzo cienkich warstw zaprawy malarskiej lub braku zaprawy, jest stosowane niekiedy wypełnianie ubytków firmowymi farbami akrylowymi, nanoszonymi za pomocą pęzelków. Takie uzupełnienie może równocześnie pełnić funkcje uzupełnienia barwnego ${ }^{109}$.

Niekiedy możliwe jest uzupełnianie ubytków zaprawy przed wykonaniem reperacji lokalnych podobrazia w sytuacji, gdy obraz ma znaczne uszkodzenia płótna. Wówczas na docięte latki jest nanoszony kit i tak przygotowane wkleja się na styk w ubytki podłoża ${ }^{110}$.

\subsection{Wyrównywanie powierzchni kitów}

Kity założone w ubytki malowidła o gładkiej powierzchni muszą być opracowane w tej samej płaszczyźnie, którą ma otaczająca wypełnienie oryginalna powierzchnia, co w przypadku aplikowania materiału z nadmiarem oznacza zeszlifowanie. Dawniej do tego celu używano poprzecznie ciętych kawałeczków drewna jodły, zwilżonego korka, sproszkowanego pumeksu lub wierzby ${ }^{111}$. Obecnie do wyrównywania nadmiarów kitu najczęściej sto-

108 B. J. Rouba, J. Dudała, Konserwacja Choragwi Procesyjnych ze Świecia, „Ochrona Zabytków”, 1995, nr 2, s. 189-196.

109 Przykład rozwiązania: P. Miller, Dokumentacja konserwatorska XVII-wiecznego obrazu holenderskiego przedstawiajacego pejzaż ze sztafażem, nr inw. ZKMiRP 686, Toruń 1993, s. 28-29; autor zastosowal farby akrylowe zmodyfikowane temperami prod. Talens - biela tytanową i umbrą naturalną, aby zapobiec ciemnieniu wypełnienia.

110 Przykład rozwiązania: M. Bachulska, Dokumentacja konserwatorska obrazu „Portret kobiety z perłami”, nr inw. ZKMiRP 851, Torun 1997.

111 K. Nicolaus, op. cit., s. 243. 
suje się korek, drewno balsy lub szmatkę (lnianą albo bawełnianą) zwilżone - w zależności od charakteru spoiwa w kicie - wodą lub benzyną lakową. $\mathrm{Na}$ te materiały można naciągnąć też kawałek delikatnej skórki. Szlifowanie polega na przesuwaniu zwilżonego materiału drobnymi, okrężnymi ruchami po powierzchni kitu. Jego nadmiary zamienione w rzadką mase usuwa się systematycznie za pomocą często zmienianych, wilgotnych wacików. Należy unikać wprowadzania zbyt dużej ilości wody, gdyż może to spowodować wymywanie kitu poniżej wymaganego poziomu. W takiej sytuacji konieczne będzie uzupełnienie wypełnienia kolejną porcją kitu i ponowne wyrównywanie. W przypadku obrazów wrażliwych na wodę lub rozpuszczalnik kity muszą być wyrównane mechanicznie z użyciem ostrego skalpela, ewentualnie papieru ściernego o drobnej granulacji lub pałeczki z włókna szklanego. Kity woskowo-żywiczne z niewielką ilością wypełniaczy można też pocierać kawałkiem materiału bawełnianego lub nylonowego owiniętego wokół palca - wytwarzane w ten sposób ciepło spowoduje rozmiękczenie powierzchniowej warstwy kitu i zbieranie nadmiarów w tkaninę. Dobrze wyrównane kity mają wyraźne, ostre brzegi, nie zachodzą na warstwę malarską i maja jednakowy z nią poziom. Aby to osiągnąć, podczas trwania pracy jej postępy powinny być uważnie sprawdzane w bocznym świetle, co pozwoli upewnić się, że powierzchnia ubytków jest dobrze dopasowana do oryginalnej powierzchni obrazu - ani za wysoka, ani za niska. Zasada ta obowiązuje też podczas następnego etapu prac, tj. opracowywania faktury.

\subsection{Opracowywanie faktury}

Każda powierzchnia malarska ma swoją własną szczególną fakture. Tylko w wyjątkowych przypadkach jest ona tak gładka, że wystarcza jedynie wyrównanie i wygładzenie kitów. Najczęściej fakturalna powierzchnia malowidła jest wypadkową działania artysty, sposobu nakładania przez niego farb w procesie twórczym (impasta, dukt pędzla itp.), jak również efektów starzenia i zmian materiałów użytych w obrazie: płótna, gruntu i warstwy malarskiej (spękania, rozstępy powstałe w wysychających farbach itp.). Jeśli $\mathrm{w}$ dalszym postępowaniu przewiduje się imitatorskie wykonanie barwnych uzupełnień w taki sposób, aby po tym zabiegu ubytek nie był widoczny, 
wówczas uzupełniany obszar musi mieć tę samą fakture, jaką ma otaczająca kit warstwa malarska.

Historyczne metody odwzorowania faktury na powierzchni kitów polegały na przyciskaniu do miękkiego wypełnienia metalowych pieczęci, stempli i modeli oraz na odciskaniu w świeżej zaprawie kawałków płótna. Niekiedy stosowano także wstawianie w kitowane partie kawałeczków płótna lub malarskich destruktów obrazów. Metoda ta miała na celu zbliżenie struktury ubytku do oryginalnej powierzchni ${ }^{112}$. Nowsze metody polegają na odciskaniu lub odlewaniu powierzchni kitu w formie zdjętej z fragmentu płótna lub z powierzchni warstwy malarskiej.

Knut Nicolaus ${ }^{113}$ podaje podział technik opracowywania faktury na dwie grupy:

1. Opracowywanie faktury wykorzystujące stosowaną masę kitującą (with the filling putty):

a) podczas aplikowania kitu - z możliwością uzyskania pożądanej faktury podczas zakładania kitu w taki sposób, aby nie było konieczne dodatkowe opracowywanie, konserwator ma do czynienia stosunkowo rzadko. Może to nastąpić, gdy np. płynna mieszanina jest nanoszona pędzlem w cienkiej warstwie tak, że po wyschnięciu odwzorowuje splot płótna i nie wymaga szlifowania ${ }^{114}$;

b) po wyschnięciu kitu, przez szlifowanie lub zeskrobywanie - w tym przypadku konserwator dysponuje całym szeregiem skalpeli o rozmaitych kształtach, narzędzi dentystycznych, igieł, końcówek kauterów, delikatnych pilniczków, pałeczek z włókna szklanego itp. narzędzi, za pomocą których możliwe jest opracowanie pożądanej faktury przez drapanie, skrobanie, wycinanie, rzeźbienie w suchym i wyszlifowanym do poziomu warstwy malarskiej kicie. Możliwości, jakie oferuje ta technika, zależą w dużej mierze od

112 Ibidem, s. 244, 251.

113 Ibidem, s. 244-251.

114 Przykład takiego rozwiązania: B. Rouba, Konserwacja obrazu Zofii Stryjeńskiej „Taniec z gitara”, „Ochrona Zabytków”, 1980, nr 1, s. 71; autorka jako kit zastosowała Lascaux Primer z kredą w stosunku 1:1, którego konsystencja pozwalała na precyzyjne naniesienie pędzlem w granicach ubytków. Szlifowanie kitu nie było możliwe ze względu na temperową warstwę malarską konserwowanego obrazu. 
rodzaju użytej masy, doboru odpowiedniego narzędzia i umiejętności osoby wykonującej zabieg;

c) z użyciem pozytywowych lub negatywowych form - technika ta polega na odciskaniu faktury w kicie, który jeszcze nie całkiem wysechł, jest nieco wilgotny lub został ogrzany (jeśli jest termoplastyczny). Najprostszą metodą odwzorowania faktury przez przyciskanie modelu jest odciskanie kawałka płótna (forma pozytywowa) w świeżo naniesionym kicie klejowo-kredowym, jednakże uzyskuje się takim sposobem negatyw faktury płótna w kicie. Zastosowanie formy negatywowej, będącej odlewem z powierzchni obrazu, pozwala na dokładne dopasowanie faktury kitu do powierzchni oryginalnej. W ten sposób jest możliwe „przeniesienie” na wypełnienie faktury płótna, duktu pędzla czy nierówności spekkanej warstwy malarskiej. Do wykonania form negatywowych wykorzystuje się obecnie kauczuk silikonowy $^{115}$ i żywice syntetyczne na bazie żywic epoksydowych ${ }^{116}$. Procedura odciskania zależy od rodzaju zastosowanej masy i polega na: a) przyciśnięciu modelu do wypełnienia, a po wyschnięciu i stwardnieniu kitu - oddzieleniu obu materiałów, b) przyciśnięciu ogrzewanego modelu do termoplastycznego kitu (woskowego lub na bazie BEVA) i usunięciu go po wystudzeniu obu materiałów.

2. Opracowywanie faktury na wypełnieniu (on the filling putty):

a) po całkowitym wyschnięciu wypełnienia z użyciem pędzla i substancji „fakturowej” - odwzorowanie faktury przeprowadza się na wyszlifowanym, wyrównanym kicie i polega na imitowaniu duktu pędzla lub impastowego opracowania malarskiego w naniesionym materiale "fakturowym”. Funkcje „fakturowych” substancji może pełnić rozrzedzony kit, akrylowe, temperowe i gwaszowe farby z tub, mieszaniny pigmentów z różnymi spoi-

115 Kauczuki silikonowe służące do wykonywania form są substancjami dwuskładnikowymi, wulkanizującymi na zimno. Charakteryzują się małym skurczem, znikomą przyczepnością do większości materiałów i znaczną elastycznością. Cechy te pozwalają na zdjęcie wiernej formy nawet z subtelnie opracowanej powierzchni. Por. J. Ciabach, Kauczuki silikonowe, [w:] idem, Żywice i tworzywa sztuczne, s. 161-163.

116 Żywice epoksydowe spotykane w handlu mają wiele postaci: od 100\% żywic podstawowych do kompozycji epoksydowych, bedacych roztworami lub dyspersjami. Żywice epoksydowe są używane do odlewania rzeźb i płaskorzeźb - we współczesnej rzeźbie i pozłotnictwie. Por. J. Ciabach, Żywice epoksydowe, [w:] idem, Żywice i tworzywa sztuczne, s. 127-148. 
wami lub woskiem pszczelim - z dodatkiem lub bez żywic i wypełniaczy. Płynne, rozrzedzone substancje są odpowiednie do nanoszenia pędzlami, natomiast zagęszczone nadają się do modelowania i cięcia dentystycznymi szpatułkami. Jeśli to konieczne, uzupełniająca praca (podrzeźbienie) może być później wykonana innymi narzędziami;

b) w kitówce $\mathrm{z}$ negatywową formą stosowaną na wypełnionym ubyt$\mathrm{ku}$ - różnica w stosunku do metody z użyciem pozytywowych lub negatywowych form odciskanych w wilgotnym lub ogrzanym kicie polega na tym, że w tym przypadku masą wypełnia się negatywową formę i jeszcze przed wyschnięciem aplikuje na uzupełnianą partię;

c) przez dodanie fakturalnych intarsji ${ }^{117}$ - relief lub intarsja fakturalna jest odlewem wykonanym poza obrazem za pomocą negatywowej formy o odpowiednio odwzorowanej fakturze. Forma może być wykonana z kauczuku silikonowego, z cienkiego arkusza cyny albo aluminium (arkusz metalu stabilizuje się warstwą gruntu klejowo-kredowego), a wypełnia sie ją substancja „fakturową”. Całość dopasowuje się w ubytek (niewypełniony lub wypełniony częściowo) i nakłada, po czym zdejmuje się formę.

Jak łatwo zauważyć, wiele $\mathrm{z}$ tych technik opiera się na stosowaniu negatywowych form zdjetych $\mathrm{z}$ oryginalnej powierzchni konserwowanego obrazu. Oferują one rozwiązanie stosunkowo proste, szybkie, bezpieczne dla obiektu i gwarantujące pozytywny efekt estetyczny, pod warunkiem użycia właściwych materiałów do wykonania form w połączeniu z odpowiednimi kitami. W latach 60. XX wieku proponowano stosowanie gipsu do wykonania formy ${ }^{118}$, który jednak ze względu na brak elastyczności, kruchość i niską precyzję odlewu nie jest odpowiednim materiałem ${ }^{119}$. Począwszy od lat 70., rozpoczęto badania nad zastosowaniem żywic syntetycznych do uzyskania form. Metode sporządzania negatywowych modeli z płynnej żywicy

117 K. Nicolaus, op. cit., s. 251; autor podaje, że pierwszym konserwatorem, który szczegółowo opisał tę metode, była S. Reschke: S. Reschke, Die gekittete Fehlstelle und ihre Strukturierung. Diploarbeit. FH Cologne, 1990.

118 B. Slansky, Technika malarstwa, t. 2: Badanie, s. 241.

119 D. Nowacka, op. cit., s. 96. 
Araldite CY $221^{120}$, której efekty oceniano jako zadowalające, jako pierwszy opracował M. Graf ${ }^{121}$. Próby z użyciem kauczuku silikonowego autor uznał za nieudane z powodu nadmiernej miękkości tworzywa, deformującego się podczas odciskania w kitach. Dorota Nowacka ${ }^{122}$, badająca na gruncie polskim przydatność materiałów i metod opisanych przez M. Grafa: Araldite CY 221 i kauczuku silikonowego ${ }^{123}$ (a dodatkowo także gipsu) w połączeniu z różnymi typami materiałów wypełniających, stwierdziła ich dużą przydatność i efektywność. Szczególnie wysoką ocenę autorka wystawiła modelom z Araldite - charakteryzującym się wiernością, precyzją i odpowiednią głębokością reliefu - dającym bardzo dobre odwzorowanie faktury, zwłaszcza w połączeniu z kitami kredowymi na bazie spoiw akrylowych ${ }^{124}$. Na początku lat 80 . J. Green i J. Seddon ${ }^{125}$ przeprowadzili eksperymenty z produktami silikonowymi Reposil Light i Reposil Putty ${ }^{126}$, a także Silastic $504^{127}$ i dyspersją polichlorku winylu Vinagel $116^{128}$. Autorzy dowiedli przydatności produktu Reposil Putty dla największej liczby powierzchni - od delikatnych i płytkich do mocnych reliefów, natomiast Reposil Light ocenili jako odpowiedni do odwzorowania delikatnych faktur. Vinagel 116, co prawda, znakomicie odtwarzał faktury, ale wymagał ogrzewania w temperaturze $150-170^{\circ} \mathrm{C}$ przez 20 minut, z kolei Silastic 504 okazał się najmniej przydatny i najtrudniejszy w formowaniu ${ }^{129}$. W najnowszych publikacjach ${ }^{130}$, jako materiał odpowiedni do zdjęcia modelu faktury z powierzchni olejnej i akrylowej warstwy ma-

120 Araldite CY 221 + Harter HY 2967 prod. Ciba-Geigy Gmbh, Wehr/Baden, Szwajcaria.

121 M. Graf, Abformung von Oberflachenstrukturen in Kittstellen, „Maltechnik-Restauro", 1974, no. 2, s. 107-109.

122 D. Nowacka, op. cit., s. 92-96.

123 Kauczuk silikonowy Polastosil M-69 prod. Zakład Doświadczalny Silikonów w Nowej Sarzynie.

124 D. Nowacka, op. cit., s. 95.

125 J. Green, J. Seddon, op. cit.

126 Reposil Light i Reposil Putty - prod. Beide de Trey AG, Zurich.

127 Silastic 504 - prod. Dow Corning International Ltd.

128 Vinagel 116 - prod. Vinatex Ltd., Special Products Division, New Lane, Havant, Hants, England.

129 J. Green, J. Seddon, op. cit., s. 81/2/12-6.

130 K. Nicolaus, op. cit., s. 249. 
larskiej, polecany jest indyjski kauczuk silikonowy ${ }^{131}$, który może być wielokrotnie wykorzystywany, dający miękki, elastyczny i wyrazisty odcisk.

Mimo oczywistych korzyści oferowanych przez wyżej wymienione metody i środki, trzeba pamiętać o związanych z nimi, pewnych ograniczeniach. Wyborowi konkretnego materiału musi towarzyszyć świadomość jego ewentualnych wad i zagrożeń, które niesie dla warstwy malarskiej. W przypadku zdejmowania odcisku z powierzchni obrazu obowiązują wszelkie środki ostrożności. Jeśli to konieczne, należy w odpowiedni sposób zabezpieczyć powierzchnię warstwy malarskiej przez naniesienie warstwy interwencyjnej, aby cząstki substancji oryginalnej nie przywierały i nie były odrywane od podłoża wraz ze zdejmowaną formą. Innym zagrożeniem może być powodowanie przez niektóre substancje ${ }^{132}$ trwałych przebarwień i zaplamień w chudych warstwach malarskich. W takim przypadku substancja taka musi zostać uznana za nieodpowiednią i zastąpiona inną, bardziej bezpieczną dla obiektu.

Powyższy przegląd środków i metod pozwala na uzmysłowienie sobie, z jak złożonym zagadnieniem mamy do czynienia, gdy mówimy o zabiegu uzupełniania ubytków zaprawy. Jego waga i znaczenie nadal bywają niedoceniane, traktowane po macoszemu - czego dowodem jest brakjego szerszego omówienia w literaturze przedmiotu czy dokumentacjach konserwatorskich. Czasy, w jakich żyjemy, promują szybkie i proste rozwiązania, ale nie w każdej dziedzinie są one możliwe do zaakceptowania. Dobro zabytku otoczonego troską konserwatora jest wartością, która nie może przegrywać z szybkością i (czasem, niestety, towarzysząca jej) bylejakością działań. Na każdym etapie konserwacji i restauracji jest konieczna refleksja - świadoma i odpowiedzialna decyzja o zastosowaniu środków i metod najwłaściwszych dla indywidualnie traktowanego obiektu. Wybór odpowiedniego materiału do uzupełnienia ubytków zaprawy i sposób jego wprowadzenia w zabytkową strukture jest

131 Wackersilikone RTV-M 539 + 5\% Harter T46, Wacker-Chemie, Munich.

132 Indyjski kauczuk silikonowy zawiera w swym składzie 2-6\% nieprzereagowanych olejów silikonowych, które mogą penetrować w warstwy malarskie i gruntu, powodując nieodwracalne przebarwienia. Por. C. V. Horie, Materials for Conservation, London 1987, s. 161. 
równie ważny, jak kończący proces restauracji zabieg uzupełniania ubytków warstwy malarskiej. Niezwykle często końcowy efekt konserwacji i restauracji zależy w dużej mierze od tego, z czego i w jaki sposób zostało uformowane podłoże do barwnej rekonstrukcji. Intencją autorki jest przybliżenie zagadnień związanych z zabiegiem uzupełniania ubytków zapraw w malowidłach sztalugowych szerszemu gronu konserwatorów oraz wzbudzenie impulsu do refleksji i poszukiwania coraz lepszych rozwiązań. 


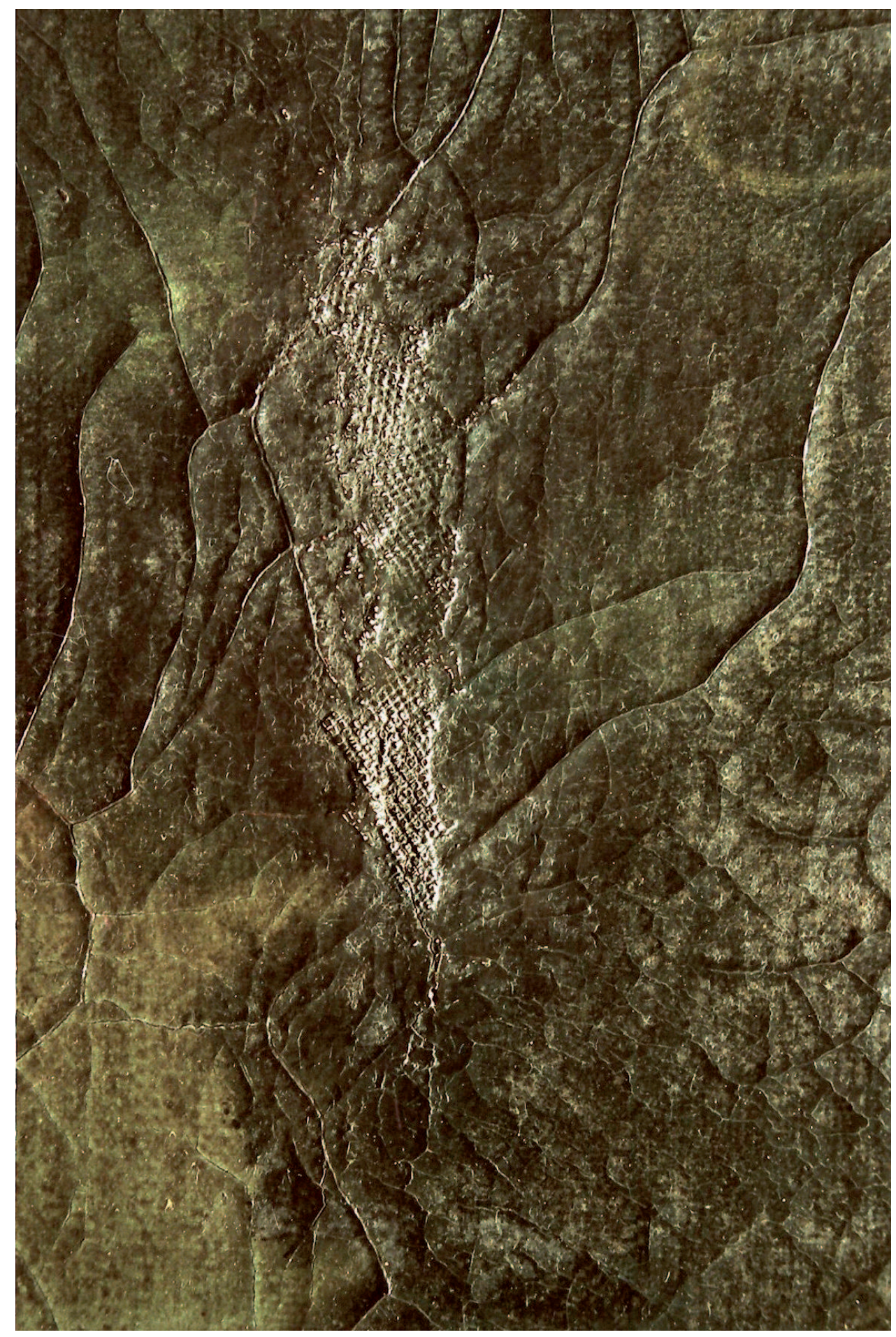

Il. 1. Przykład wadliwej faktury kitu, niedostosowanej do otaczającej ubytek warstwy malarskiej. Reprodukcja fot. 9 z Dokumentacji prac konserwatorskich i restauratorskich obrazu Ucieczka do Egiptu, nr inw. ZKMiRP 1301 (fot. P. Łopacka) 


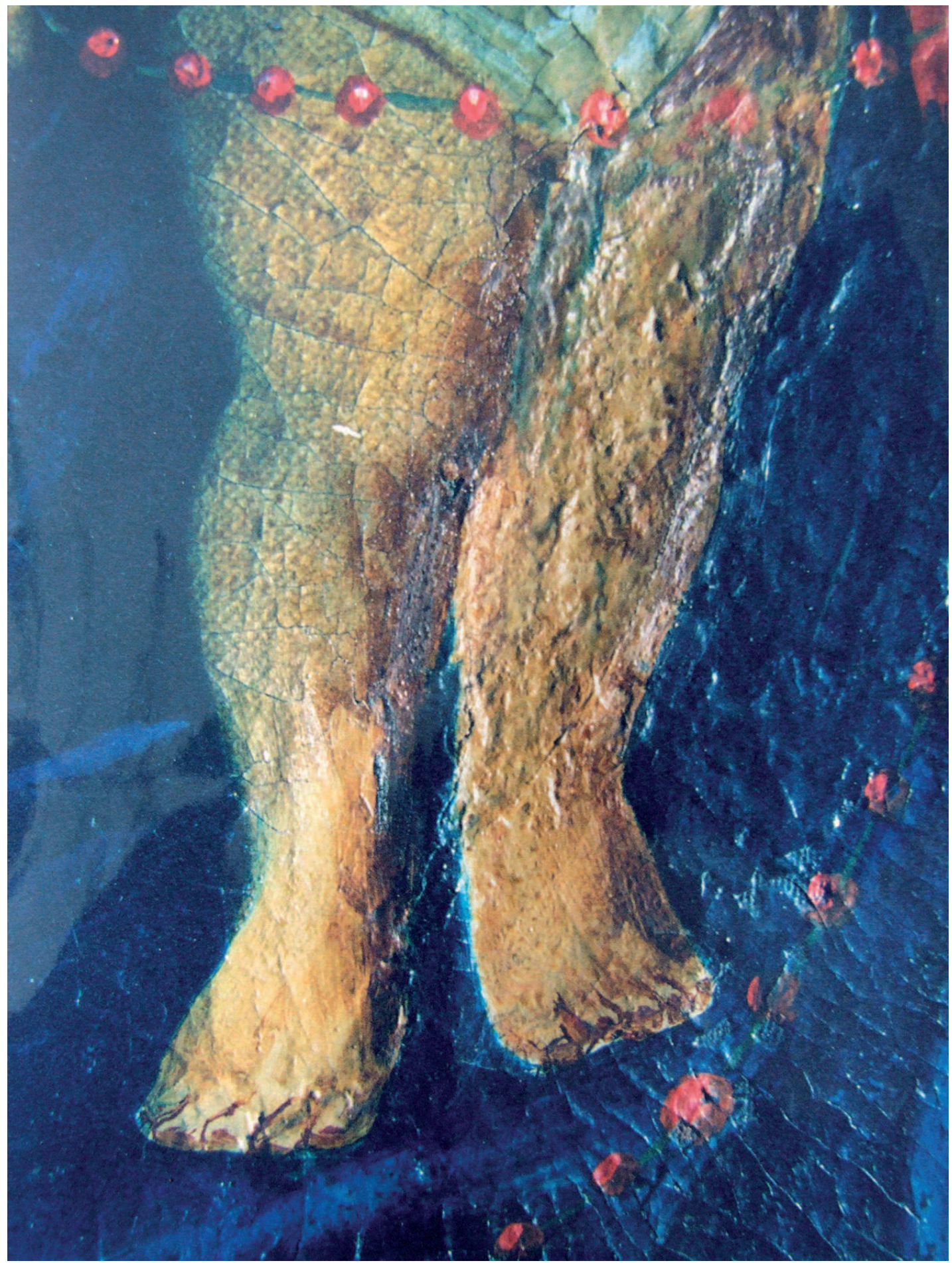

Il. 2. Nieudana rekonstrukcja wykonana na wadliwym uzupełnieniu ubytków zaprawy, założonym niedbale, zachodzącym na oryginalne opracowanie malarskie, z obcą fakturą. Reprodukcja fot. 10 z Dokumentacji prac konserwatorskich i restauratorskich obrazu Matka Boska Różańcowa ze Św. Dominikiem i Św. Katarzyna Sienénska, nr inw. ZKMiRP 1022 (fot. W. Grzesik) 


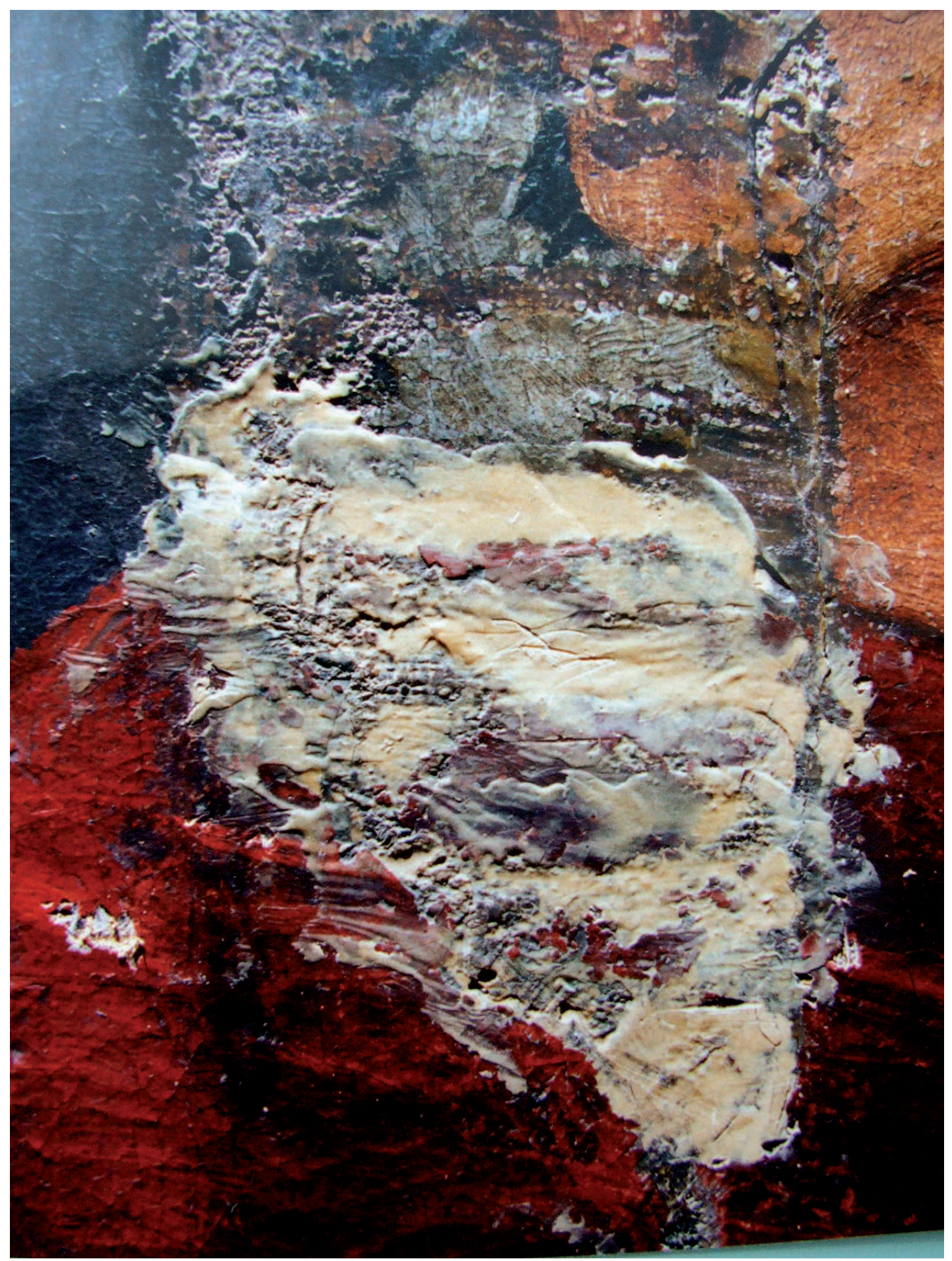

Il. 3. Woskowy kit założony szeroko, zachodzacy na warstwę malarską. Reprodukcja fot. 15 z Dokumentacji prac konserwatorskich i restauratorskich obrazu Wybór między bogactwem a miłościa, nr inw. ZKMiRP 1035 (fot. D. Lizun) 


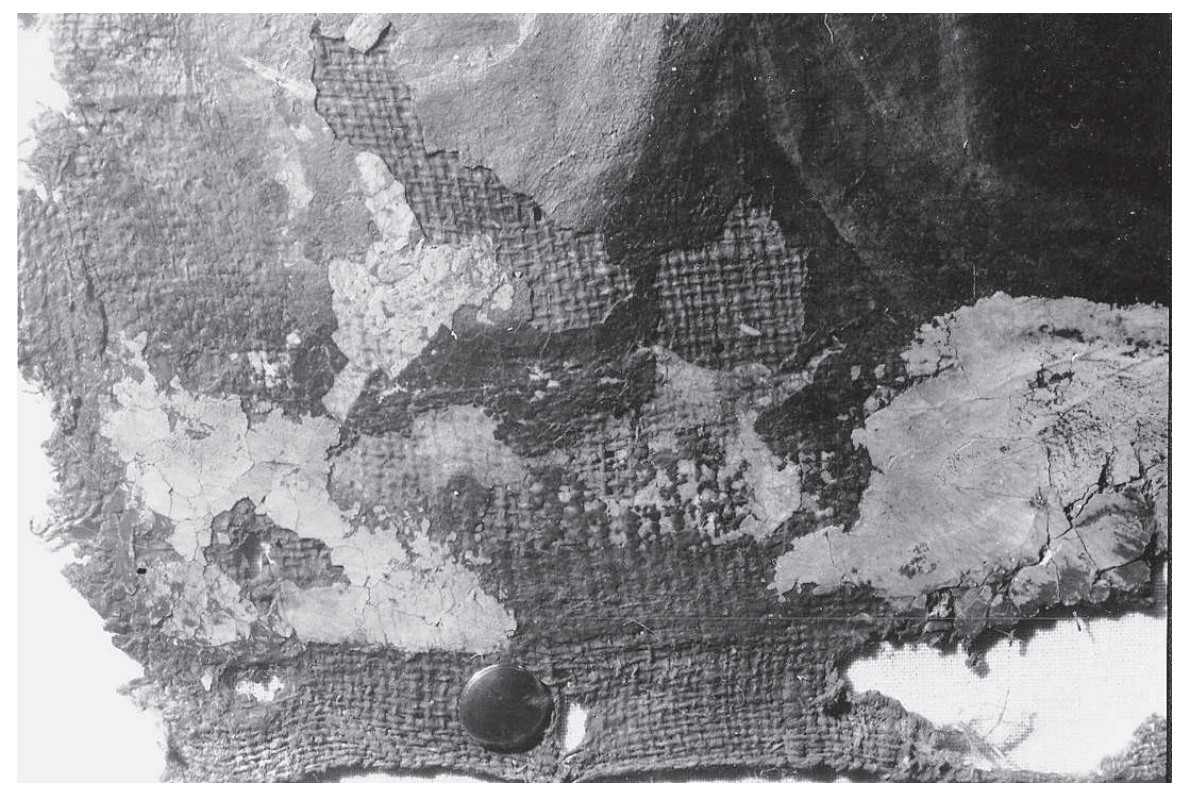

Il. 4. Wypełnienia ubytków pochodzące z dwóch ingerencji I. kity mieszczące się w ubytkach, II. kity założone szeroko, z nadmiarem, na warstwie malarskiej. Reprodukcja fot. 15 z Dokumentacji prac konserwatorskich i restauratorskich obrazu Boszki i Faony (Bachanalia), nr inw. ZKMiRP 766 (fot. P. Mikołajczyk)

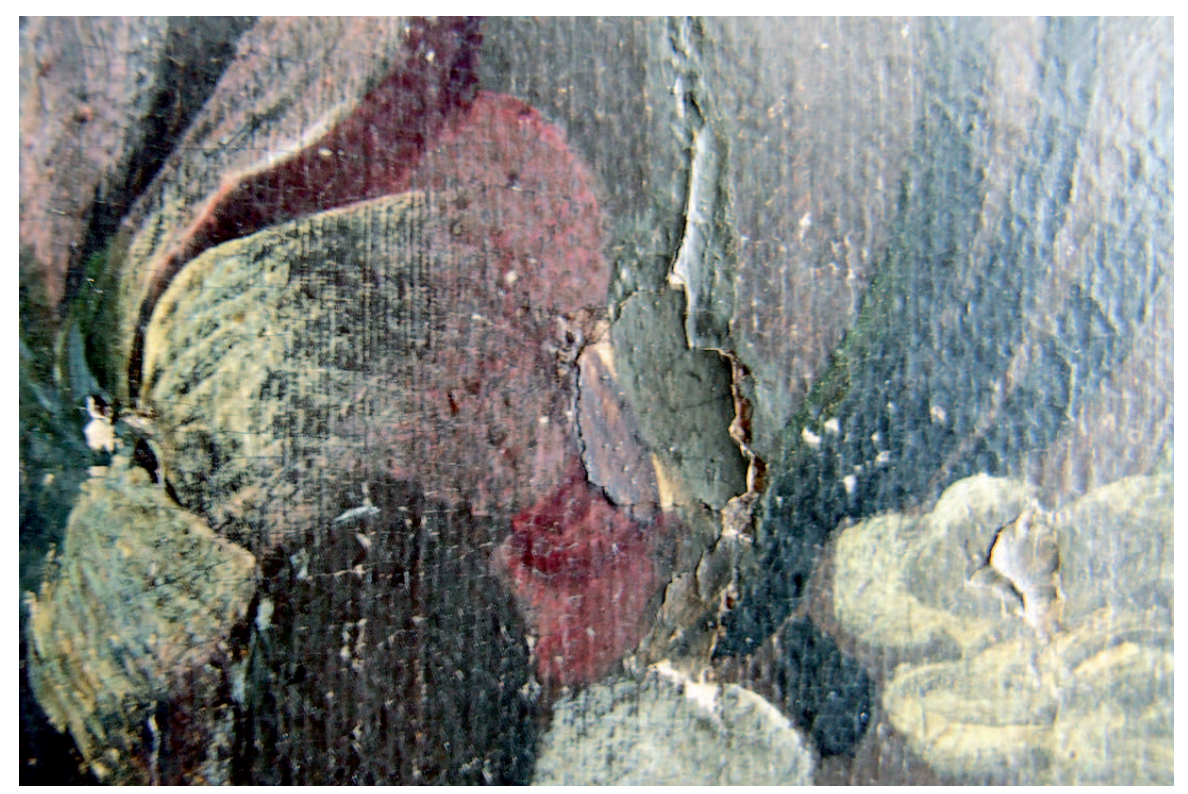

Il. 5. Zbyt mocno sklejony kit uwidocznił się w postaci zagłębionej miseczki z uniesionymi brzegami. Obraz Alegoria Pór Roku Wiosna, XVII w., Abraham Joansens (replika), XVII w., nr inw. ZKMiRP 77, wykonawcy prac konserwatorskich: Małgorzata Wesołowska, Jan Gałaszek, Torun 1968 (fot. J. Stachera) 


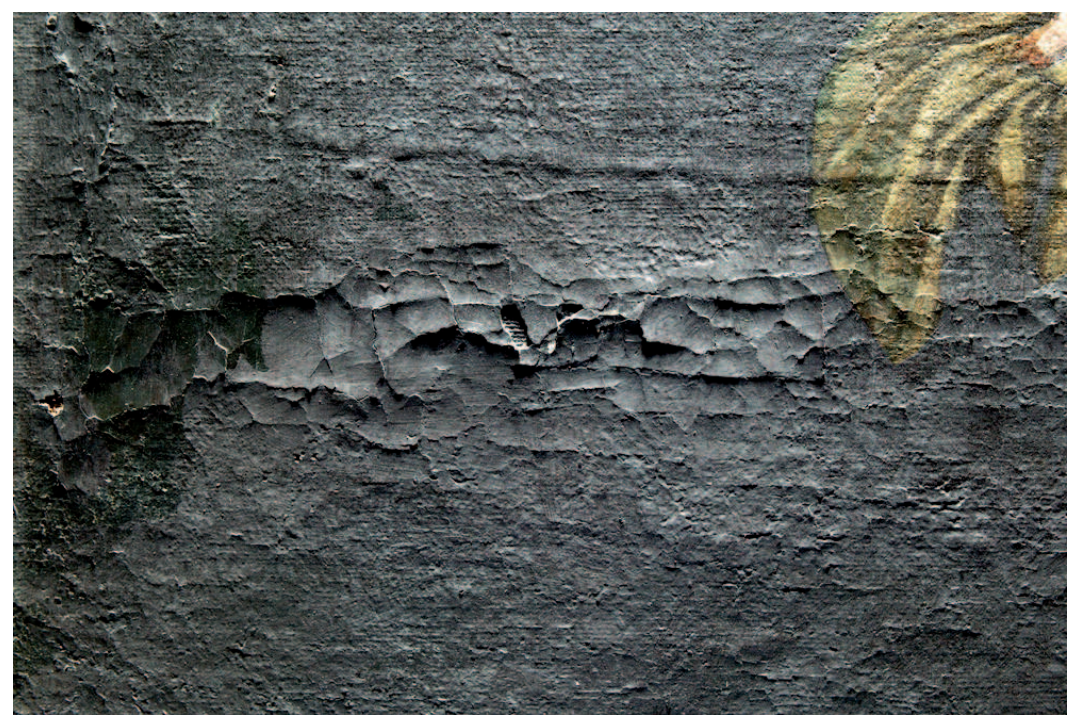

Il. 6. Wadliwy kit o odmiennej od oryginału siatce spękań, oddzielający się od płótna. Obraz Pokłon pasterzy, prace konserwatorsko-restauratorskie: A. Hadała, M. Zacharska, pod kier. prof. dr Bogumiły Rouby, dr Elżbiety Szmit-Naud, mgr Teresy Łękawy-Wysłouch i mgr Ludmiły Tymińskiej, nr inw. ZKMiRP 1283 (fot. A. Hadała, M. Zacharska)

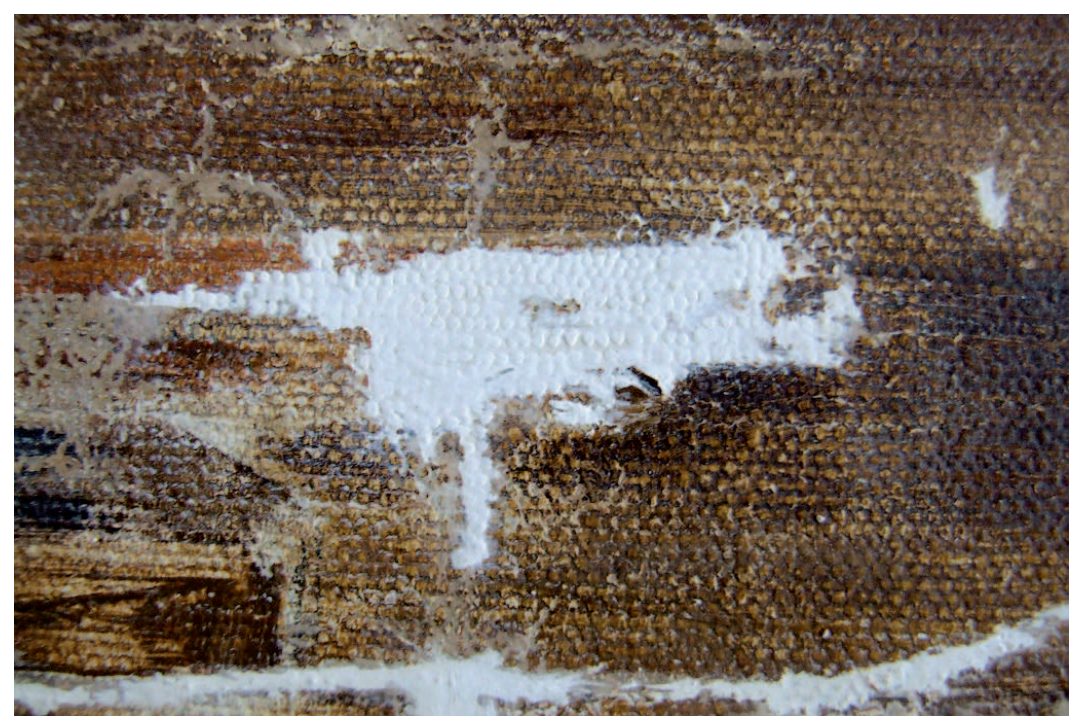

Il. 7. Opracowanie faktury naśladującej splot płótna - uzyskane przez nanoszenie kitu pędzelkiem. Obraz Adoracja Matki Bożej z Dzieciatkiem, XIX/XX w., Jacek Malczewski, prace konserwatorskie i restauratorskie: A. Szarszewska, pod kier. dr. hab. Dariusza Markowskiego i mgr Joanny Arszyńskiej, nr inw. ZKMiRP 1188 (fot. T. Łękawa-Wysłouch) 


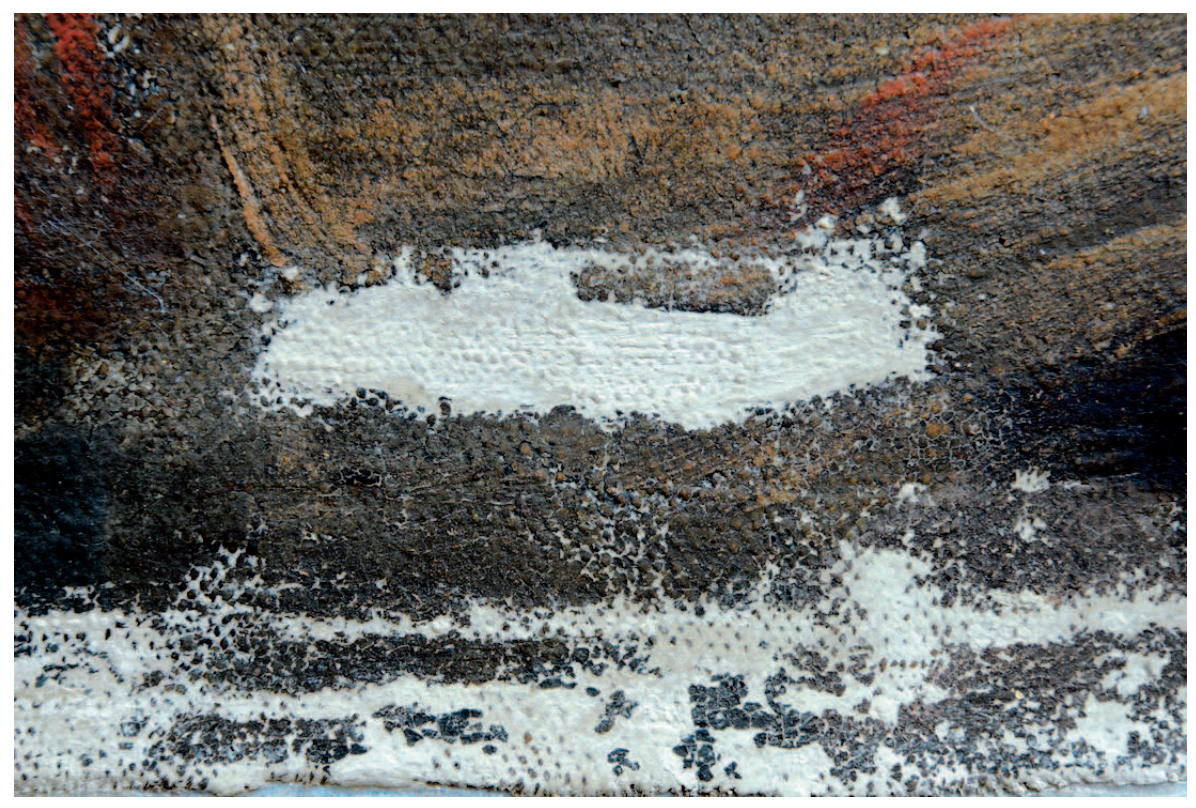

Il. 8. Opracowanie faktury, naśladującej splot płótna i dukt pędzla, zgodne z oryginalną substancją w otoczeniu ubytku. Obraz olejny na płótnie z XVIII w. - własność prywatna (fot. L. Tymińska-Widmer)

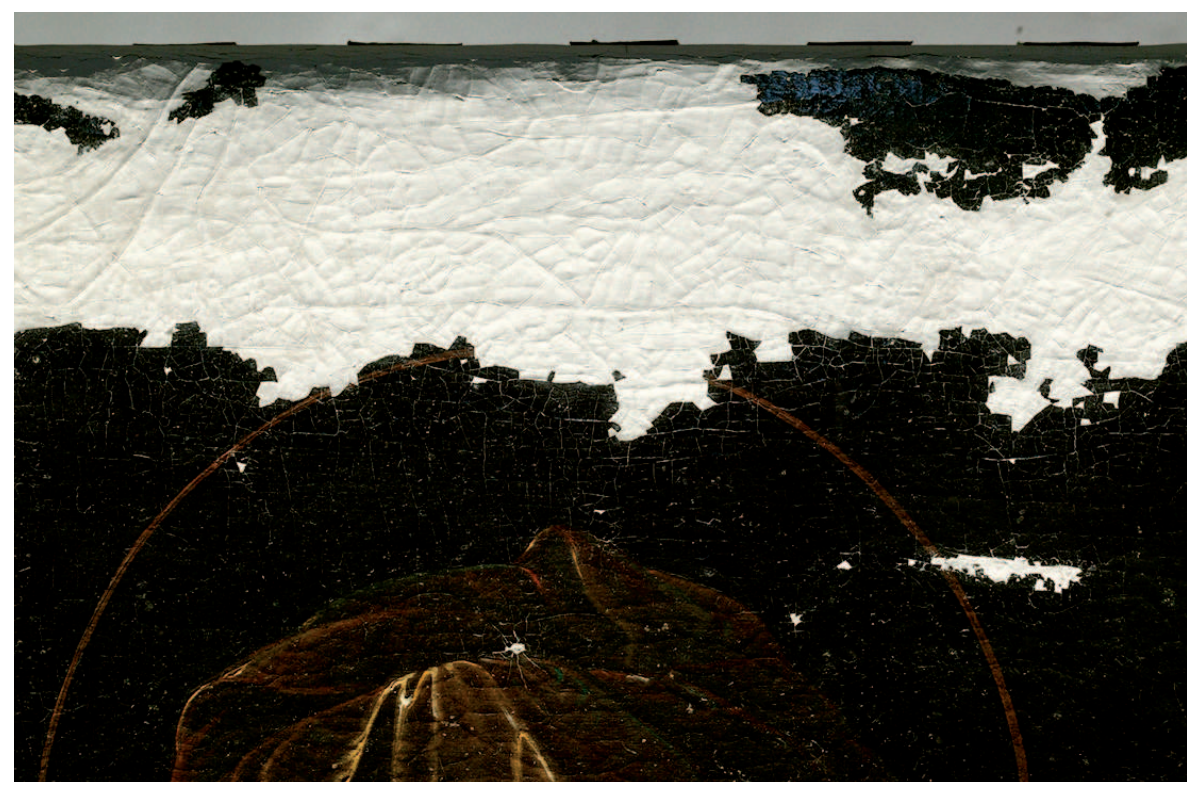

Il. 9. Właściwe opracowanie faktury kitu emulsyjnego, imitujące spekania sąsiadującej z ubytkiem warstwy malarskiej - uzyskane przez wycinanie i podrzeźbianie. Reprodukcja fot. 15 za: M. Lasek, Dokumentacja prac konserwatorskich i restauratorskich obrazu Matka Boska z Dzieciatkiem, nr inw. ZKMiRP 1175 (fot. M. Lasek) 


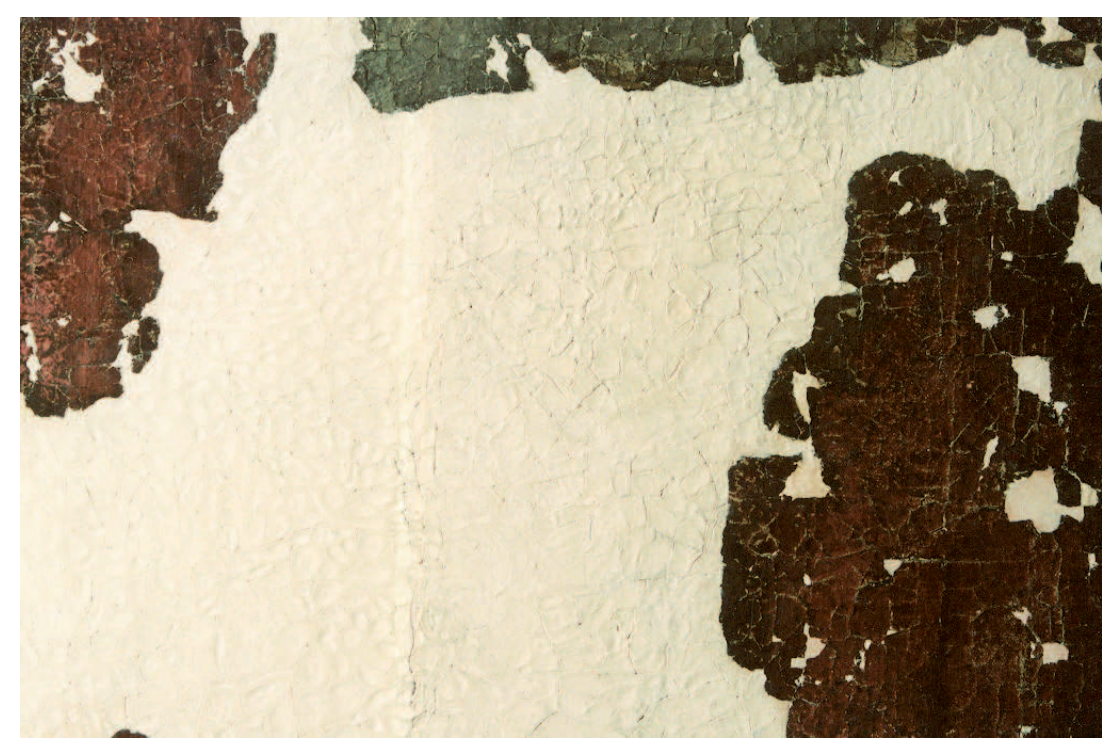

Il. 10. Właściwe opracowanie faktury kitu emulsyjnego, imitujące spękania warstwy malarskiej - uzyskane przez wycinanie i podrzeźbianie w suchym wypełnieniu. Reprodukcja fot. 39 za: E. Kallinen, Dokumentacja prac konserwatorskich i restauratorskich obrazu Matka Boska Różańcowa, nr inw. ZKMiRP 1175, Torun 2005 (fot. E. Kallinen)

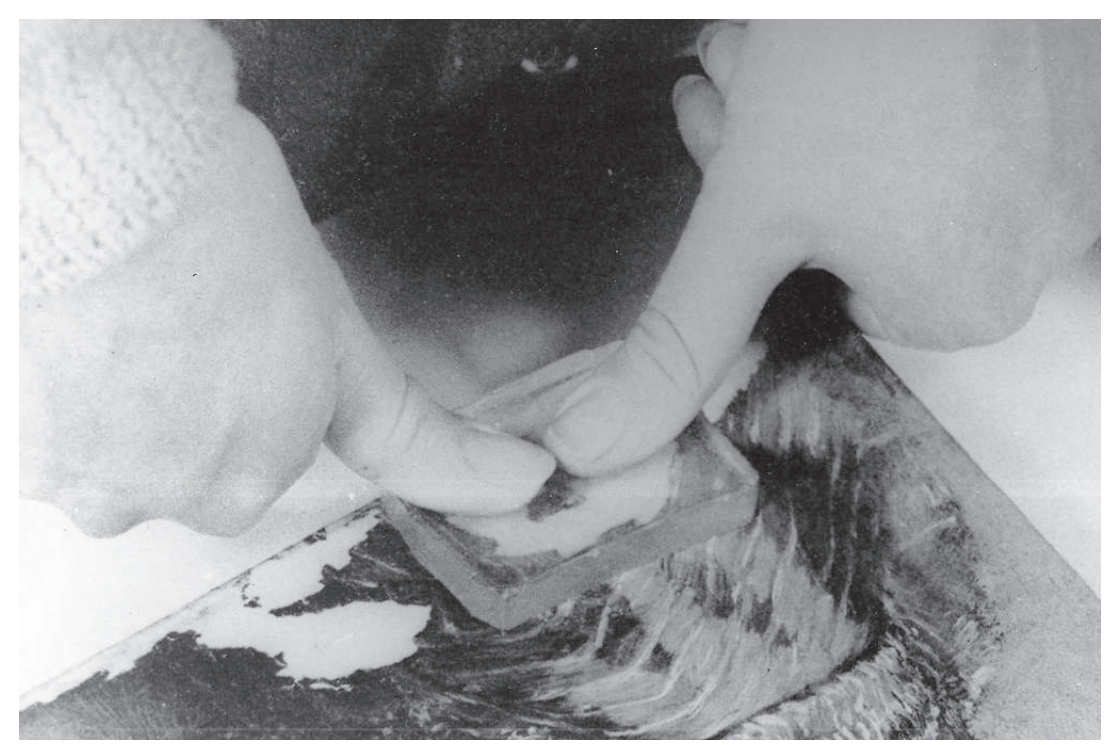

Il. 11 . Odciskanie faktury na powierzchni kitu wypełniającego ubytek z użyciem formy z Araldite CY 221. Reprodukcja fot. 16 za: D. Nowacka, Problematyka opracowywania faktur w kitach stosowanych do uzupełnień ubytków malowideł sztalugowych, praca magisterska wykonana w ZKMiRP UMK, Torun 1986 (fot. D. Nowacka) 


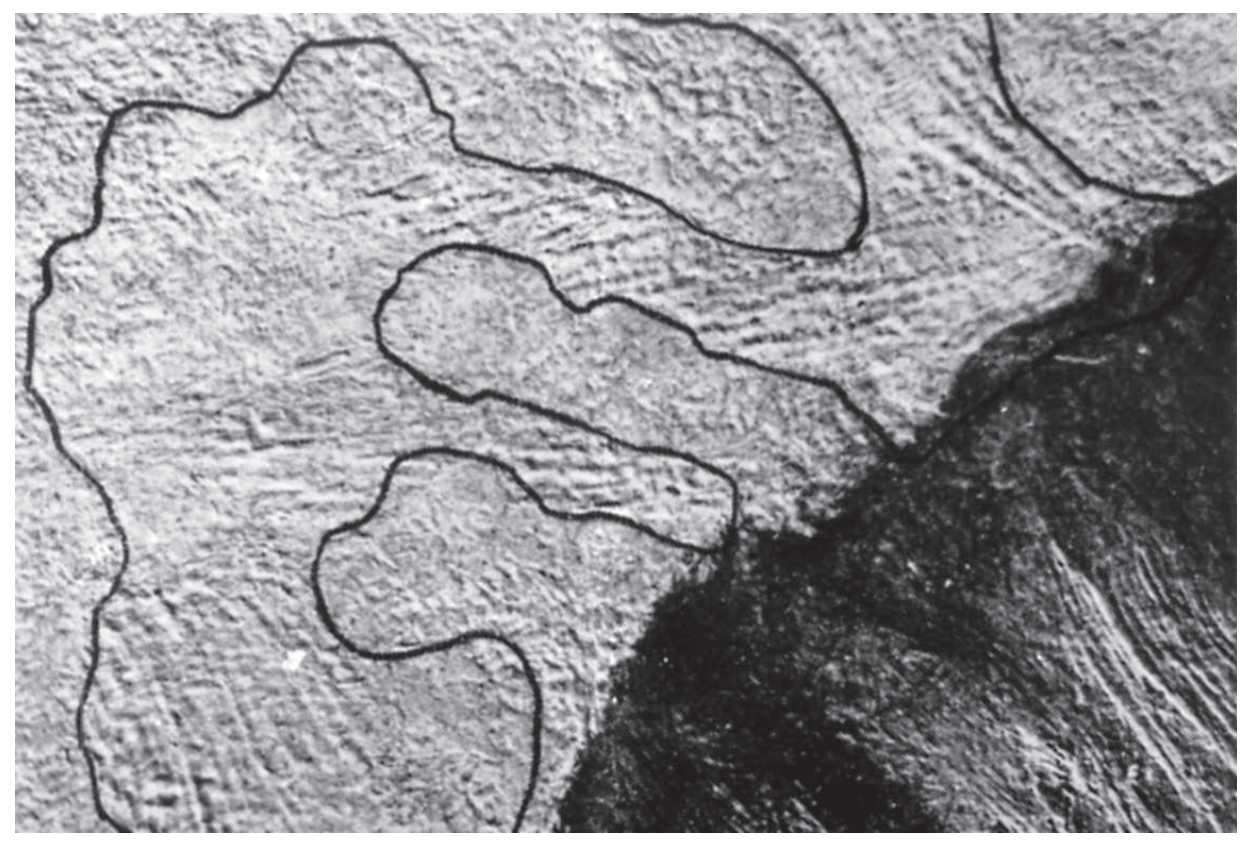

Il. 12. Przykład faktury uzyskanej metodą odciskania z użyciem formy negatywowej. Linią obwiedziono obszar uzupełniony z odciśnięta faktura. Reprodukcja fot. 17 za: D. Nowacka, Problematyka opracowywania faktur w kitach stosowanych do uzupełnień ubytków malowideł sztalugowych, praca magisterska wykonana w ZKMiRP UMK, Torun 1986 (fot. D. Nowacka) 


\section{Summary}

\section{Reintegration of priming injuries in paintings on canvas - the review of materials and methods}

In the article the literature on reintegrating injuries of priming in canvas paintings has been reviewed. The criteria of selecting the materials have been discussed, the means used in that procedure have been characterised taking into consideration their division into two groups according to the types of binding media, that is fillers based on natural binding media (glue-, emulsion-, oil-, bees wax- and bees wax and resin-based) and those based on synthetic resins (BEVA 371, polyvinyl alcohol, polyvinyl acetate, polyacrylate resins). Also the methods used to apply and to work-out the injuries have been discussed, starting form preparation of the injuries themselves, application of fillers, levelling their surface and developing their texture. 